\title{
MENGUKUR NIAT PENGGUNA APLIKASI AKUNTANSI DENGAN PENDEKATAN THEORY TECHNOLOGY ACCEPTANCE MODEL (TAM)
}

\author{
Zufiyardi $^{1}$, Yusmaniarti ${ }^{2}$, Fraternesi ${ }^{3}$, Ali Ibrahim ${ }^{4}$ \\ 1,2,3,4 Department of Accounting, Faculty of Economics, Universitas Muhammadiyah Bengkulu, Indonesia; \\ ${ }^{4}$ Management of Information System and Business (MISaB) Research Group, Faculty of Computer \\ Science, Universitas Sriwijaya, Indonesia. \\ Email:1'yusmaniarti@umb.ac.id; ${ }^{2}$ zufiyardi@umb.ac.id; ${ }^{4}$ fraternesi @umb.ac.id; \\ ${ }^{4}$ aliibrahim@unsri.ac.id \\ * Correspondent author: yusmaniarti@umb.ac.id
}

\begin{abstract}
ABSTRAK
Pertumbuhan perekonomian Indonesia didorong oleh peran penting sektor UKM. Akuntansi telah mengalami perkembangan teknologi informasi yang cukup pesat. Adanya aplikasi akuntansi memudahkan aktivitas dan pencatatan akuntansi. Semua rangkaian kegiatan dalam akuntansi seperti menjual, posting ke buku besar, menyusun neraca saldo dan laporan keuangan dapat dikerjakan melalui program aplikasi akuntansi. Penelitian ini bertujuan untuk mengetahui apakah ada atau tidaknya aspek perilaku yang signifikan terhadap penerimaan teknologi bagi pelaku UKM yang belum menggunakan aplikasi akuntansi. Model penelitian yang digunakan adalah Technology Acceptance Model (TAM). Populasi penelitian adalah pelaku UKM di Bengkulu. Teknik pengumpulan sampel dengan convenience sampling. Teknik analisis data menggunakan Smart PLS 3.2 pendekatan Partial Least Square (PLS). Hasil penelitian menunjukkan bahwa semua hipotesis diterima secara signifikan melalui statistik (P-value $<0,05)$. Pertama, Perceived Usefulness ada pengaruh signifikan terhadap Attitude $(0,00<0,05)$. Kedua, Perceived Ease Of Use ada pengaruh signifikan terhadap Perceived Usefulness $(0,00<0,05)$. Ketiga, Perceived Ease Of Use ada pengaruh signifikan terhadap Attitude $(0,00<0,05)$. Keempat, Attitude ada pengaruh signifikan terhadap Behavioral Intention $(0,00<0,05)$. Berdasarkan hasil penelitian bahwa pengguna memiliki sikap, niat penggunan serta perilaku yang baik dalam menerima pengadopsian aplikasi akuntansi.
\end{abstract}

\section{Kata kunci : Perceived Usefulness, Perceived Ease Of Use, Attitude, Behavior Intention, TAM,} Smart PLS

\begin{abstract}
Indonesia's economic growth is driven by the important role of the SME sector. Accounting has experienced a fairly rapid development of information technology. The existence of an accounting application facilitates accounting activities and records. All series of activities in accounting such as selling, posting to the general ledger, preparing trial balances and financial reports can be done through an accounting application program. This study aims to determine whether or not there are significant behavioral aspects to technology acceptance for SMEs who have not used accounting applications. The research model used is the Technology Acceptance Model (TAM). The research population is SMEs in Bengkulu. The sampling technique used is convenience sampling. The data analysis technique used Smart PLS 3.2 Partial Least Square (PLS) approach. The results showed that all hypotheses were accepted significantly through statistics (P-value <0.05). First, Perceived Usefulness has a significant effect on Attitude (0.00
\end{abstract}


$<0.05)$. Second, Perceived Ease Of Use has a significant effect on Perceived Usefulness $(0.00$ $<0.05)$. Third, Perceived Ease Of Use has a significant effect on Attitude $(0.00<0.05)$. Fourth, Attitude has a significant effect on Behavioral Intention $(0.00<0.05)$. Based on the results of the study that users have good attitudes, intentions and behavior in accepting the adoption of accounting applications.

Keywords : Perceived Usefulness, Perceived Ease Of Use, Attitude, Behavior Intention, TAM, Smart PLS

\section{PENDAHULUAN}

Kegagalan pola pembangunan ekonomi yang bertumpu pada konglomerasi usaha besar telah mendorong para perencana ekonomi untuk mengalihkan upaya pembangunan dengan bertumpu pada pemberdayaan Usaha Kecil dan Menengah (UKM). Usaha Kecil Menengah (UKM) merupakan salah satu sektor strategis dalam perekonomian nasional. Hal ini dapat dilihat dari besarnya penyerapan tenaga kerja oleh sektor UKM. Berdasarkan data Kementerian Koperasi dan UKM menyebutkan bahwa pada tahun 2013 jumlah tenaga kerja di sektor UKM sebesar 9.519.616 pekerja dengan rincian 5.570.231 pekerja di usaha kecil dan 3.949.385 di usaha menengah. Adapun jumlah unit usaha kecil sebanyak 654.222 unit dan unit usaha menengah sebanyak 52.106 unit. Pertumbuhan perekonomian Indonesia didorong oleh peran penting Sektor UKM. Dengan adanya sektor UKM, pengangguran akibat angkatan kerja yang tidak terserap dalam dunia kerja menjadi berkurang. Sektor UKM pun telah terbukti menjadi pilar perekonomian yang tangguh saat terjadi krisis ekonomi tahun 1998, setelah krisis ekonomi pun UKM masih berperan bahkan dijadikan tulang punggung perekonomian karena secara alamiah lebih dinamis ketimbang perusahaan besar. Namun dalam perkembangannya pengembangan usaha kecil masih menghadapi beberapa kendala seperti tingkat kemampuan, ketrampilan, keahlian, manajemen sumber daya manusia, kewirausahaan, pemasaran dan keuangan (Kuncoro, 2007). UKM sangat berat dalam menghadapi persaingan dengan perusahaan-perusahaan besar dan lebih modern. Kemampuan bersaing di pasar sangat menentukan kelangsungan hidup suatu perusahaan, demikian pula dengan UKM. Di Indonesia sebagian UKM menjalankan usahanya dengan cara-cara tradisional, padahal saat ini perusahaan bersaing melalui kecanggihan teknologi dan IT untuk bisa memenangkan persaingan.

Dilansir dari (www.online-pajak.com), tarif PPh Final UMKM resmi turun dari $1 \%$ menjadi 0,5\% (syarat dan ketentuan berlaku). Perubahan tarif PPh Final UMKM tersebut tercantum dalam Peraturan Pemerintah No. 23 Tahun 2018, perubahan tarif ini diberlakukan sejak 1 Juli 2018. Peraturan pemerintah tentang Pajak penghasilan atas Penghasilan Dari Usaha yang Diterima atau Diperoleh Wajib Pajak yang Memiliki Peredaran Bruto Tertentu tersebut merupakan pengganti atas PP No. 46 Tahun 2013. Direktorat Jenderal Pajak Kementerian Keuangan memberikan kemudahan bagi pelaku Usaha Mikro, Kecil dan Menengah (UMKM) untuk melaksanakan kewajibannya membayar pajak. Jika kondisi bisnis tengah merugi, wajib pajak bisa membuat 
pembukuan agar tarif pajaknya menjadi lebih rendah, sesuai dengan omzet. Aturan pembukuan tersebut tertuang dalam PP No. 23 Tahun 2018.

SIA menghasilkan informasi keuangan yang bisa dipercaya, relevan, tepat waktu, dapat dipahami dan teruji kebenarannya untuk membantu dalam proses pengambilan keputusan ekonomis (Rosita 2013). "Sistem Informasi Akuntansi (SIA) adalah kumpulan sumber daya manusia dan peralatan, yang dirancang untuk mengubah data keuangan dan data lain menjadi informasi yang dikomunikasikan kepada berbagai pihak pengambil keputusan”, Bodnar dan Hopwood (2004). Penelitian tentang niat berperilaku (behavioral intention) dalam penggunaan teknologi dilakukan dengan menggunakan Theory Technology Acceptance Model (TAM). TAM menawarkan suatu penjelasan yang kuat dan sederhana untuk penerimaan teknologi dan perilaku penggunanya (Venkatesh dan Moris, 2000). TAM dilandasi dari Theory of Reasoned Action (TRA) yang dikemukakan Ajzen dan Fisbein (1980) dalam Jogiyanto (2007). TRA menyatakan bahwa seseorang akan menerima komputer jika komputer memberikan manfaat kepada para pemakainya. TAM secara khusus digunakan dalam bidang sistem informasi untuk memprediksi penerimaan dan penggunaan dalam pekerjaan individual pemakai (Oladipupo, 2014 dalam Darmaningtyas dan Ketut, 2017).

Menurut Davis (1989) TAM adalah sebuah teori sistem informasi yang dirancang untuk menjelaskan bagaimana pengguna mengerti dan menggunakan sebuah teknologi informasi. Santoso (2004) menggunakan konstruk asli TAM yang dibuat oleh Davis (1989), yaitu persepsi kegunaan (perceived usefulness) merupakan manfaat yang diharapkan oleh pengguna teknologi informasi dalam melaksanakan tugas, persepsi kemudahan penggunaan (perceived ease of use) sebagai suatu tingkatan dimana seseorang percaya bahwa penggunaan sistem tertentu dapat mengurangi beban usaha seseorang dalam mengerjakan sesuatu, sikap (attitude), dimana sikap suka atau tidak suka terhadap penggunaan suatu produk. Sikap suka atau tidak suka terhadap suatu produk ini dapat digunakan untuk memprediksi perilaku niat seseorang untuk menggunakan suatu produk atau tidak menggunakannya, niat perilaku (behavioral intention) dimana tingkat penggunaan sebuah teknologi komputer pada seseorang dapat diprediksi dari sikap perhatian pengguna terhadap teknologi tersebut, misalnya keinginan menambah pendukung, motivasi untuk tetap menggunakan, serta keinginan untuk memotivasi pengguna lainnya, penggunaan senyatanya (actual use) dimana seseorang akan puas menggunakan sistem jika mereka meyakini bahwa sistem tersebut mudah digunakan dan akan meningkatkan produktifitas mereka. Amoroso dan Gardner (2004) TAM menambahkan beberapa konstruk eksternal yaitu jenis kelamin (gender), pengalaman (experience), kerumitan (complexity), dan kesukarelaan (voluntariness).

Keberhasilan dalam suatu sistem informasi bergantung pada bagaimana proses menjalankan sistem tersebut, kemudahan penggunaan sistem bagi pemakai, dan kemampuan pemakai sistem. Salah satu model untuk memprediksi dan menjelaskan penggunaan komputer adalah Technology Acceptance Model (TAM) (Jun Dai and Heli, 2013). Secara teoritis dan praktis TAM merupakan model yang dianggap pantas dalam menjelaskan bagaimana user menerima sebuah sistem. TAM menyatakan bahwa behavioral intention to use ditentukan oleh dua keyakinan yaitu: pertama, persepsi kemanfaatan (perceived usefulness) yang didefinisikan sebagai sejauh mana seseorang 
yakin bahwa menggunakan sistem akan meningkatkan kinerjanya. Kedua, persepsi kemudahan (perceived ease of use) yang didefinisikan sebagai sejauh mana seseorang yakin bahwa penggunaan sistem adalah mudah.

Sistem akuntansi berbasis komputerisasi dapat membantu UKM untuk meningkatkan usaha dan mengatasi masalah yang ada di UKM. UKM sangat berkepentingan terhadap penggunaan sistem informasi berbasis komputer agar bisa berdaya saing dengan entitas yang lebih besar, namun masih banyak UKM yang belum menggunakan aplikasi akuntansi dalam usahanya (Paidi, Yusmaniarti,Y., 2017). Penelitian ini mengukur niat untuk menggunakan aplikasi akuntansi pada UKM menggunakan pendekatan Theory Technology Acceptance Model. Objek penelitian ini adalah UKM di Kota Bengkulu.

\section{Review of Literature}

\section{Theory of Reasoned Action (TRA)}

Theory of Reasoned Action (TRA) pertama kali diperkenalkan oleh Martin Fishbein \& Ajzen (1980) dalam Shinta (2009). Teori ini menghubungkan antara keyakinan (belief), sikap (attitude), kehendak (intention) dan perilaku (behavior). Theory of Reasoned Action (TRA) menyatakan bahwa individu akan menggunakan komputer jika mereka mengetahui adanya keuntungan atau hasil positif dalam penggunaan komputer tersebut Fisben dan Ajzen (1980). Secara lebih sederhana, teori ini mengatakan bahwa seseorang akan melakukan suatu perbuatan apabila ia memandang perbuatan itu positif dan bila ia percaya bahwa orang lain ingin agar ia melakukannya.

\section{Technology Acceptance Model (TAM)}

Technology Acceptance Model (TAM) pertama kali dikembangkan oleh Davis (1989) dan kemudian dipakai serta dikembangkan kembali oleh beberapa peneliti seperti Adam et al. (1992) Szajna (1996), Igbaria et al. (1995) dan Venkatesh dan Davis (2000). Modifikasi model TAM dilakukan oleh Venkantesh (2002) dengan menambahkan variable trust dengan judul: Trust enhanced Technology Acceptance Model, yang meneliti tentang hubungan antar variabel TAM dan trust. Beberapa model penelitian telah dilakukan untuk menganalisis dan memahami faktor-faktor yang mempengaruhi diterimanya penggunaan teknologi komputer, diantaranya yang tercatat dalam berbagai literatur dan referensi hasil riset di bidang teknologi informasi adalah seperti TRA, Theory of Planed Behaviour (TPB), dan TAM yang dikembangkan oleh Davis F.D (1989) merupakan salah satu model penelitian yang paling banyak digunakan dalam penelitian teknologi informasi, karena model penelitian ini lebih sederhana dan mudah diterapkan (Iqbaria, 1995) dalam Sarana (2000).

Menurut Davis (1989) TAM adalah sebuah teori sistem informasi yang dirancang untuk menjelaskan bagaimana pengguna mengerti dan menggunakan sebuah teknologi informasi. TAM menggunakan TRA dari Fishbein dan Ajzen (1967) yang digunakan untuk melihat bagaimana tingkat adopsi responden dalam menerima teknologi informasi. TAM adalah suatu model untuk menjelaskan dan memprediksikan penerimaan pengguna terhadap suatu teknologi. TAM merupakan pengembangan TRA dan memprediksi penerimaan pengguna terhadap teknologi berdasar pengaruh dua faktor, yaitu persepsi kemanfaatan (perceived usefulness) dan persepsi kemudahan 
penggunaan (perceived ease of use) (Davis, 1989). Kedua konstruk tersebut merupakan perbedaan mencolok yang ada pada TAM jika dibandingkan dengan TRA dan TPB. Selain itu, TAM juga tidak terdapat konstruk norma subjektif (subjective norm) dan kontrol perilaku (perveived behavioral control). Konstruk lain dalam TAM sama dengan TRA, hanya karena lebih dikhususkan untuk penggunaan teknologi, maka istilahnya pun menyesuaikan. Model TAM ditunjukkan pada Gambar 2.1

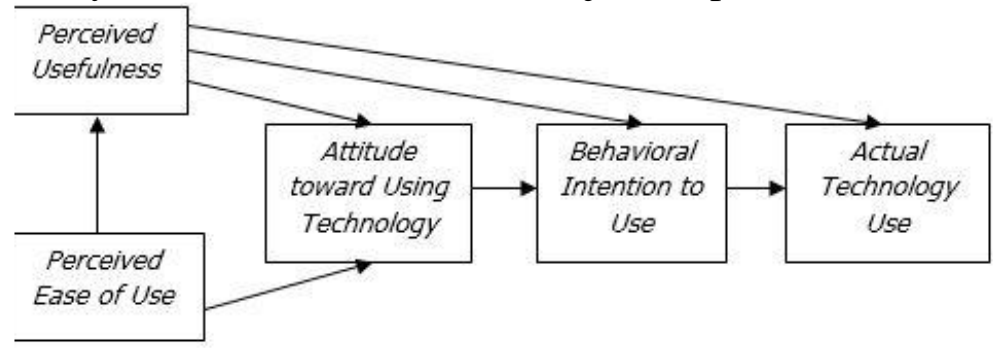

Gambar 2.1.

Technology Acceptance Model (Jogiyanto, 2008: 113)

TAM memiliki 5 konstruk utama, yaitu: (1) Perceived usefulness (kegunaan), (2) Perceived ease of use (kemudahan penggunaan), (3) Attitude toward using technology (sikap), (4) Behavioral intention to use (intensi), dan (5) Actual technology use (penggunaan teknologi sesungguhnya). Penjelasan masing-masing konstruk adalah sebagai berikut.

Konstruk pertama adalah perceived usefulness yang selanjutnya disebut kegunaan. Kegunaan didefinisikan sebagai sejauh mana seseorang percaya bahwa menggunakan suatu teknologi akan meningkatkan kinerja pekerjaannya (Davis, 1985: 26). Konstruk ini dipengaruhi oleh konstruk kemudahan penggunaan. Penelitian terdahulu menunjukkan bahwa kegunaan merupakan konstruk yang paling banyak signifikan dan penting yang mempengaruhi sikap, intensi dan perilaku (Jogiyanto, 2008: 114). Terdapat 6 indikator untuk mengukur konstruk kegunaan yaitu pekerjaan lebih cepat selesai (work more quickly), meningkatkan kinerja (job performance), meningkatkan produktivitas (increase productivity), meningkatkan efektivitas kerja (effectiveness), memudahkan pekerjaan (makes job easier) dan berguna (useful) (Davis, 1989 dalam Jogiyanto 2008; 152).

Konstruk kedua adalah perceived ease of use yang selanjutnya disebut kemudahan penggunaan. Kemudahan penggunaan didefinisikan sebagai sejauh mana orang percaya bahwa menggunakan suatu teknologi akan bebas dari upaya (Davis, 1985: 25). Konstruk ini memengaruhi konstruk kegunaan, sikap, intensi dan penggunaan teknologi sesungguhnya. Namun yang paling signifikan adalah pengaruh ke konstruk kegunaan, sementara terhadap konstruk lain pengaruhnya tidak signifikan (Jogiyanto, 2008: 115). Terdapat 6 indikator untuk mengukur konstruk kemudahan penggunaan yaitu kemudahan sistem untuk dipelajari (easy of learn), kemudahan system untuk dikontrol (controllable), interaksi dengan system yang jelas dan mudah dimengerti (clear and understandable), fleksibilitas interaksi (flexibility), mudah untuk terampil menggunakan sistem (easy to become skillful) dan mudah untuk digunakan (easy to use) (Davis, 1989 dalam Jogiyanto, 2008: 152). 
Konstruk ketiga adalah attitude toward using technology yang selanjutnya disebut sikap. Sikap dapat didefinisikan sebagai perasaan positif atau negatif dari seseorang jika harus melakukan perilaku yang akan ditentukan (Davis dkk, 1989 dalam Jogiyanto, 2008: 116). Dalam model TAM, sikap berpengaruh pada intensi serta dipengaruhi oleh kemudahan penggunaan dan kegunaan. Jogiyanto (2008: 116) juga menyatakan bahwa dalam penelitian-penelitian yang sudah pernah dilakukan, sebagian menunjukkan bahwa sikap memiliki pengaruh positif pada intensi, namun sebagian yang lain juga menunjukkan bahwa sikap tidak memiliki pengaruh yang signifikan ke intensi. Oleh sebab itu, ada penelitian TAM tidak menyertakan konstruk sikap dalam modelnya.

Konstruk keempat adalah behavioral intention to use yang selanjutnya disebut intensi. Mengacu pada Gambar 2.1, intensi memiliki pengaruh pada penggunaan teknologi sesungguhnya serta dipengaruhi oleh sikap dan kegunaan. Terdapat 2 indikator untuk mengukur konstruk intensi, yaitu penggunaan sistem untuk menyelesaikan pekerjaan (carrying out the task) dan rencana pemanfaatan di masa depan (planned utilization in the future) (Amoroso and Gardner, 2004).

Konstruk kelima adalah actual technology use yang selanjutnya disebut penggunaan teknologi sesungguhnya atau penggunaan. Dalam TAM, penggunaan teknologi sesungguhnya setara dengan istilah perilaku (behavior) pada TRA namun untuk digunakan dalam konteks teknologi.

\section{Penelitian Terdahulu}

Lu et al., (2010), meneliti tentang An empirical study of on-line tax filling accaptance model: Integrating TAM and TPB. Penelitian ini menjelaskan faktorfaktor penentu yang mempengaruhi pembayar pajak untuk menggunakan sistem pengarsipan pajak on-line. Hasil empiris menunjukkan semua hipotesis yang diajukan dalam penelitian ini didukung. Kegunaan persepsian memiliki pengaruh positif yang signifikan terhadap kontrol perilaku persepsian (koefisien jalur $=0,269$ ) dan sikap (koefisien jalur $=0,369$ ). Selain itu kemudahaan penggunaan persepsian berpengaruh signifikan terhadap manfaat pembayar pajak persepsian (koefisien jalur $=0,550$ ), kontrol perilaku persepsian (koefisien jalur $=0,679$ ) dan sikap (koefisien jalur $=0,226$ ). Korelasi dengan faktor TAM terhadap faktor TPB juga signifikan. Dengan kata lain, ada korelasi dengan faktor-faktor di dalam kedua teori tersebut. Temuan tersebut belum pernah dibahas sebelumnya dalam kontribusi utama penelitian ini. Pada hubungan antara norma dan faktor TPB, norma sosial berpengaruh positif signifikan terhadap sikap (koefisien jalur $=0,108$ ) dan norma subjektif (koefisien jalur $=0,123$ ). Hasil empiris juga menunjukkan bahwa faktor norma (norma sosial dan norma moral) memiliki dampak positif pada faktor TPB (sikap dan norma subjektif). Penelitian ini mengusulkan bahwa sikap adalah faktor utama yang mempengaruhi minat perilaku pengarsipan pajak on-line. Hasil empiris menunjukkan bahwa minat perilaku pengarsipan pajak on-line ditentukan oleh kontrol perilaku persepsian (koefisien jalur $=0,343$ ), sikap (koefisien jalur $=0,449$ ), dan norma subjektif (koefisien jalur $=0,102$ ). Pengarsipan pengajuan pajak secara on-line memiliki efek positif yang signifikan terhadap perilaku pengarsipan pajak on- 
line (koefisien jalur $=0,592)$. Temuan ini sesuai dengan Ajzen (1985). Dalam aspek keterbatasan penelitian dan studi selanjutnya, penelitian ini mengharapkan untuk menerima 1000 kuesioner. Namun situasi sebenarnya lebih buruk dari yang diharapkan (kuesioner respon adalah 422). Lu et al., (2010) menyarankan agar penelitian berikut dapat mengunjungi staf senior di perusahaan selain menggunakan kuesioner on-line. Tingkat pengetahuan lebih tinggi sehingga memungkinkan untuk mendapatkan kuesioner yang lebih valid. Kuesioner cetak kertas adalah metode lain untuk mengumpulkan sampel (karena menggunakan kuesioner on-line, peneliti tidak dapat menguji pembayar pajak yang jarang menggunakan internet). Penelitian ini hanya berfokus pada pembayar pajak yang memiliki pengalaman menggunakan pengajuan pajak on-line. Lu et al., (2010) menyarankan agar tindak lanjut studi dapat menargetkan pembayar pajak yang tidak pernah menggunakan sistem pengarsipan pajak on-line untuk mempelajari faktor komentar dan penerimaan kelompok pengalaman menggunakan sistem pengarsipan pajak on-line dan tidak memiliki pengalaman dalam sistem.

Dreana (2012), melakukan penelitian tentang "Analisis faktor - faktor yang mempengaruhi penerimaan pengguna SIMAWEB di Fakultas Ekonomi dan Bisnis Universitas Diponegoro : Integrasi TAM dan TPB”. Dari 13 hipotesis yang diajukan, terdapat 5 hipotesis ditolak dan 8 hipotesis diterima. Kegunaan persepsian tidak berpengaruh terhadap kontrol perilaku persepsian. Kemudahan penggunaan persepsian tidak berpengaruh terhadap kontrol perilaku persepsian. Norma sosial tidak berpengaruh terhadap sikap. Norma sosial tidak berpengaruh terhadap norma subyektif. Norma moral tidak berpengaruh terhadap sikap. Kegunaan persepsian berpengaruh positif terhadap sikap. Kemudahan penggunaan persepsian berpengaruh positif terhadap kegunaan persepsian. Kemudahan penggunaan persepsian berpengaruh positif terhadap sikap. Norma moral berpengaruh positif terhadap norma subyektif. Kontrol perilaku persepsian berpengaruh positif terhadap niat perilaku penggunaan sistem. Sikap berpengaruh positif terhadap niat perilaku penggunaan sistem. Norma subyektif berpengaruh positif terhadap niat perilaku penggunaan sistem. Niat perilaku berpengaruh positif terhadap perilaku penggunaan sistem.

Amanda dan MI Mitha (2017) menyimpulkan bahwa Pendekatan Theory of Planned Behavior dalam melihat faktor-faktor yang mempengaruhi niat penggunaan SI terkomputerisasi menunjukkan bahwa hanya variabel kontrol perilaku persepsian (perceived behavior control) yang berpengaruh terhadap niat penggunaan SI terkomputerisasi. Hal ini dipicu oleh adanya persepsi para pelaku UKM bahwa menggunakan SI terkomputerisasi itu tidak sulit dan dapat mengurangi upaya (tenaga dan waktu) dalam melakukan pekerjaan, juga pekerjaan dapat dilakukan secara lebih cepat. Sedangkan variable sikap (atittude) dan norma subjektif (subjective norm) tidak berpengaruh terhadap niat (intention) atas penggunaan SI terkomputerisasi.

4. Kerangka Pemikiran

Penelitian ini merupakan replikasi dari penelitian yang dilakukan oleh Amanda dan MI Mitha (2017) tentang Faktor-faktor yang mempengaruhi niat penggunaan SI Terkomputerisasi pada UKM dengan mengubah pendekatan teori yang digunakan dari Theory Planed of Behavior menjadi Theory Technology Acceptance Model. Penelitian 
sebelumnya yang dilakukan oleh Filadelfia (2015) (dalam Amanda dan MI Mitha, 2017), menyatakan bahwa niat pelaku UMKM atas pengadaan pembukuan dipengaruhi oleh variabel sikap (attitude).

Technology Acceptance Model (TAM) yang diperkenalkan pertama kali oleh Fred D. Davis pada tahun 1989, adalah adaptasi dari TRA yang dibuat khusus untuk pemodelan penerimaan pengguna terhadap sistem informasi. TAM menganggap bahwa 2 keyakinan individual, yaitu persepsi kemanfaatan (perceived usefulness, disingkat PU) dan persepsi kemudahan penggunaan (perceived easy of use, disingkat PEOU). Berikut ini adalah gambar kerangka pemikiran penelitian berdasarkan teori TAM :

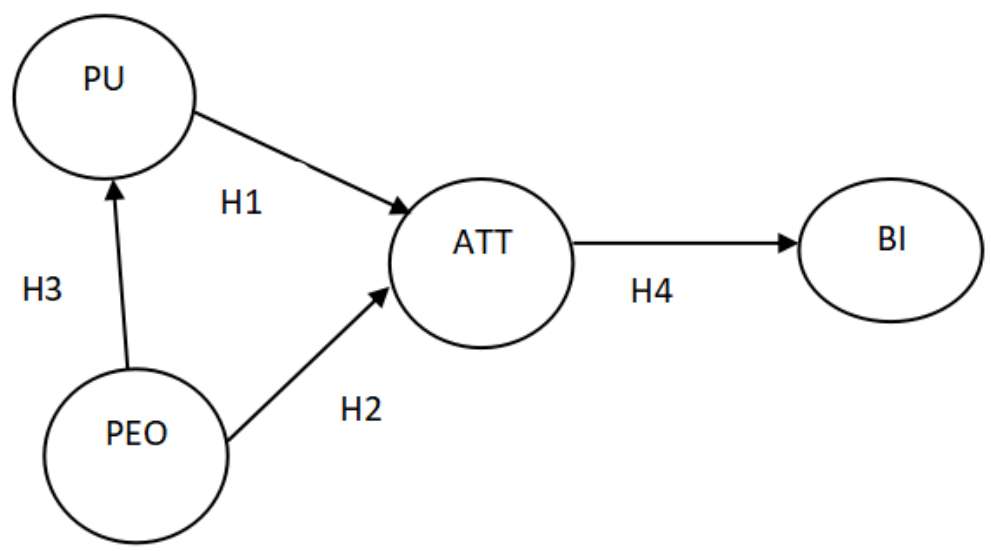

\section{Gambar 2.2 Skema Kerangka Pemikiran}

\section{a. Pengaruh Persepsi Kegunaan (Perceived Usefulness) Terhadap Sikap (Attitude).}

Perceived Usefulness didefinisikan oleh Davis (1989) merupakan tingkat kepercayaan seseorang ketika menggunakan sistem tertentu dapat meningkatkan kinerja pekerjaannya. Amoroso dan Gardner (2004) menemukan hubungan yang signifikan antara persepsi kegunaan terhadap persepsi sikap. Dalam hal ini dapat menunjukkan bahwa terdapat pengaruh yang diberikan perceived usefulness terhadap attitude pengguna dalam menerima teknologi informasi akuntansi yaitu terkait dengan penerimaan aplikasi akuntansi.

H1 : Perceived usefulness aplikasi akuntansi berpengaruh positif terhadap attitude.

\section{b. Pengaruh Persepsi Kemudahan Penggunaan (Perceived Ease Of Use) Terhadap Sikap (Attitude) Dan Persepsi Kegunaan (Perceived Usefulness).}

Pengguna akan merasa lebih mudah menggunakan sistem jika startup aplikasi menyediakan tampilan yang lebih mudah dioperasikan dan peringatan kesalahan pengisian pada saat mengakses sistem (Ramayah, et al., 2009) dalam Nugroho 2012. Pengguna akan mengetahui manfaat dari sistem tersebut jika sistem mudah digunakan (Warkentin, et al., 2002) dalam Nugroho 2012. Suseno (2009) menemukan hubungan yang signifikan antara perceived ease of use terhadap attitude. Sehingga jika pengguna berfikir bahwa sistem mudah digunakan maka pengguna mempunyai sikap positif menerima sistem aplikasi akuntansi. 
Ketika pengguna aplikasi akuntansi mempelajari dan mengerti menggunakan aplikasi akuntansi dengan lebih cepat, keefesienan penggunaan sistem tersebut juga akan meningkat. Kefesienan pengguna akan membawa pola piker pengguna bahwa sistem sangat bermanfaat bagi mereka. Pengguna dapat melakukan pembukuan keuangan dengan lebih cepat pada saat pengguna memiliki perceived ease of use yang lebih tinggi (Fu, et al., 2006) dalam Nugroho 2012. Oleh karena itu, perceived ease of use adalah faktor determinan dari perceived usefulness.

$\mathrm{H} 2$ : Perceived ease of use aplikasi akuntansi berpengaruh positif terhadap attitude.

H3 : Perceived ease of use aplikasi akuntansi berpengaruh positif terhadap perceived usefulness.

\section{c. Pengaruh Antara sikap (attitude) Terhadap Niat Perilaku (Behavioral Intention)}

Sun (2003) menemukan bahwa sikap bukan merupakan pemrediksi andal terhadap niat perilaku maupun penggunaan senyatanya. Amoroso dan Gardner (2004) menyatakan bahwa penggunaan mungkin memiliki sikap yang positif jika mereka percaya bahwa penggunaan teknologi akan meningkatkan kinerja dan produktivitas mereka. Wiyono (2008) dan Suseno (2009) menemukan hubungan yang positif signifikan persepsi sikap terhadap persepsi niat perilaku. Dalam penelitian ini peneliti ingin menguji kembali hubungan antara persepsi sikap terhadap niat perilaku penggunaan.

H4 : Attitude menerima aplikasi akuntansi berpengaruh positif terhadap Behavioral Intention menggunakan aplikasi akuntansi.

\section{METODE PENELITIAN}

\section{Jenis Penelitian}

Jenis penelitian ini adalah explanative research dengan menggunakan pendekatan kuantitatif. Menurut Singarimbun dalam Singarimbun dan Effendi (2006), explantive research merupakan penelitian yang bertujuan untuk mengukur hubungan antar variabel-variabel penelitian dan menguji hipotesa yang telah dirumuskan sebelumnya. Pada akhirnya hasil penelitian ini menjelaskan hubungan kausal antar variabel-variabel melalui pengujian hipotesis

\section{Populasi dan Sampel}

Populasi dalam Penelitian ini adalah seluruh UKM yang ada di Kota Bengkulu. Berikut ini merupakan tabel populasi UKM di Kota Bengkulu:

Tabel 3.1 Populasi UKM di Kota Bengkulu

\begin{tabular}{|l|l|}
\hline Kecamatan & Jumlah UKM \\
\hline Gading Cempaka & 27 \\
\hline Muara Bangkahulu & 28 \\
\hline Ratu Agung & 41 \\
\hline Selebar & 15 \\
\hline Singaran Pati & 36 \\
\hline Sungai Serut & 32 \\
\hline Teluk Segara & 63 \\
\hline
\end{tabular}


Metode yang digunakan untuk menentukan jumlah sampel adalah metode Convenience Sampling. Metode pengambilan sampel ini dipilih untuk memudahkan pelaksanaan penelitian dengan alasan bahwa jumlah populasi yang belum menggunakan aplikasi akuntansi tidak diketahui sehingga terdapat kebebasan untuk memilih sampel yang paling cepat dan murah. Peneliti menggunakan 50\% dari populasi untuk dijadikan sebagai sampel penelitian. Secara khusus kuesioner diberikan kepada UKM yang belum menggunakan aplikasi akuntansi. Untuk pengujian seluruh hipotesis dalam penelitian ini menggunakan metode Analisis Component Based SEM atau Partial Least square (PLS), maka besar sampel minimal yang direkomendasikan berkisar dari 30 sampai 100 pelaku UKM yang belum menggunakan aplikasi akuntansi (Imam Ghozali, 2014).

\section{Teknik Pengumpulan Data}

Metode pengumpulan data yang digunakan dalam penelitian ini adalah metode survei dengan cara menyebarkan kuesioner kepada 242 pelaku UKM di wilayah kota Bengkulu. Penyebaran kuesioner dilakukan dengan dua cara, yaitu online dan offline. Kuesioner online dibagikan kepada pelaku UKM yang terkoneksi dengan aplikasi chat WhatsApp ataupun grup chat WhatsApp, dan kuesioner offline akan langsung di antar ketempat responden. Untuk tenggang waktu pengambilan kuesioner akan ditetapkan. Kuisoner dibuat dengan kategori multiple choise dengan menggunakan skala linkert. Responden yang digunakan yaitu para pelaku UKM yang berjumlah 242 orang yang belum menggunakan aplikasi akuntansi. Penyebaran kuesioner dilakukan secara online dan offline dimulai pada tanggal 29 Desember 2018. Penyebaran secara online dilakukan di grup chat WhatsApp BDS KPP Pratama Bengkulu yang beranggotakan para pelaku UKM dan menghubungi langsung nomor HP yang terhubung dengan akun WhatsApp yang terdapat di data UKM. Penyebaran secara offline langsung ke alamat pelaku UKM. Dari 242 kuesioner yang disebarkan ada 129 kuesioner yang terkumpul, 129 (53,30\%) ini sudah memenuhi target dari peneliti yang mentargetkan $50 \%$ dari populasi, sehingga kuesioner yang didapat sudah bisa untuk dilakukan analisis pengukuran

\section{Teknik Analisis Data}

Analisis data menggunakan pendekatan Partial Least Square (PLS). Model analisis jalur PLS-SEM terdiri dari dua unsur yaitu model pengukuran (measurement model) atau outer model dan model struktural (Structural model) atau inner model. Inner model menunjukkan hubungan antara variabel laten. Sedangkan outer model menggambarkan hubungan antara variabel laten dengan variabel indikator (Widarjono, 2015; 273). Menurut Wold (1985), Teknik Partial Least Square (PLS) merupakan metode analisis yang powerful karena tidak didasarkan banyak asumsi. Data tidak harus terdistribusi normal multivariate dan sampel tidak harus besar (minimal direkomendasikan berkisar dari 30 - 100). (Ghozali, 2014; 7-9). Partial Least Square (PLS) terdapat dua macam komponen pada model kausal yaitu, model pengukuran (measurement model) dan model struktural (structural model).

Convergent validity merupakan model pengukuran dengan refleksif indikator dinilai berdasarkan korelasi antara item score/component score dengan construct 
score yang dihitung dengan PLS. Ukuran refleksif individual dikatakan tinggi jika berkorelasi lebih dari 0,70 dengan konstruk yang ingin diukur. Namun demikian untuk penelitian tahap awal dari pengembangan skala pengukuran nilai loading 0,5 sampai 0,60 dianggap cukup (Ghozali, 2014; 39).

Discriminant validity merupakan model pengukuran dengan refleksif indikator dinilai berdasarkan cross loading pengukuran dengan konstruk. Jika korelasi konstruk dengan item pengukuran lebih besar daripada ukuran konstruk lainnya, maka hal ini menunjukkan bahwa konstruk laten memprediksi ukuran pada blok mereka lebih baik daripada ukuran pada lainnya (Ghozali, 2014; 40). Menurut Fornell dan Larcker (1981), metode lain untuk mencari discriminant validity adalah membandingkan nilai square root of average variance extracted (AVE) setiap konstruk dengan korelasi antara konstruk dengan konstruk lainnya (latent variabel correlation) dalam model, maka dikatakan memiliki nilai discriminant validity yang baik (Ghozali, 2014; 40). Uji lainnya adalah menilai validitas konstruk dengan melihat nilai AVE, dipersyaratkan model yang baik kalau AVE masing-masing konstruk nilainya lebih besar dari 0,5 (Ghozali, 2014). Rumus dari AVE yaitu sebagai berikut:

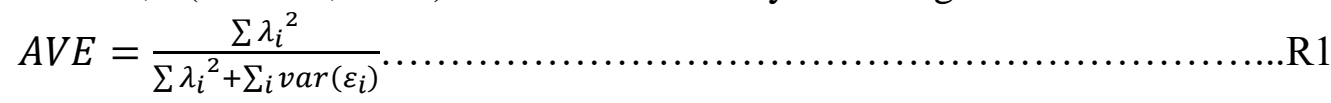

Composite reliability merupakan Blok indikator yang mengukur suatu konstruk dapat dievaluasi dengan dua macam ukuran yaitu internal consistency dan cronbach's Alpha (Ghozali, 2014; 40). Dibandingkan dengan cronbach Alpha, ukuran ini tidak mengasumsikan tau equivalence antar pengukuran dengan asumsi semua indikator diberi bobot sama. Sehingga cronbach alpha cenderung lower bound estimate reliability. Sedangkan composite reliability merupakan closer approximation dengan asumsi estimasi parameter lebih akurat (Ghozali, 2014: 4041). Berikut rumus composite reliability:

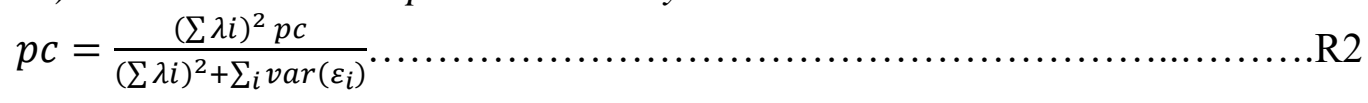

a. Nilai evaluasi Inner Model

1. Uji Path Coefficient

Evaluasi path coefficient digunakan untuk menunjukkan seberapa kuat efek atau pengaruh variabel independen kepada variabel dependen. Sedangkan coefficient determination ( $R$-Square) digunakan untuk mengukur seberapa banyak variabel endogen dipengaruhi oleh variabel lainnya. Chin menyebutkan hasil $\mathrm{R}^{2}$ sebesar 0,67 ke atas untuk variabel laten endogen dalam model struktural mengindikasikan pengaruh variabel eksogen (yang mempengaruhi) terhadap variabel endogen (yang dipengaruhi) termasuk dalam kategori baik. Sedangkan jika hasilnya sebesar 0,33 0,67 maka termasuk dalam kategori sedang, dan jika hasilnya sebesar 0,19-0,33 maka termasuk dalam kategori lemah (Ghozali, 2014).

2. Uji Kebaikan Model (Goodnes of Fit)

Penilaian goodness of fit diketahui dari nilai $Q$-Square. Nilai $Q$-Square memiliki arti yang sama dengan coefficient determination ( $R$-Square) pada analisis regresi, dimana semakin tinggi $Q$-Square, maka model dapat dikatakan semakin baik atau 
semakin fit dengan data. Adapun hasil perhitungan nilai $Q$-Square adalah sebagai berikut:

Q-Square $=1-\left[\left(1-R^{2} 1\right) \times\left(1-R^{2} 2\right) \times\left(1-R^{2} n\right)\right]$

Dalam menilai model PLS, kita mulai dengan melihat $R$-square untuk setiap variabel laten dependen. Perubahan nilai $R$-square dapat digunakan untuk menilai pengaruh variabel laten independen tertentu terhadap variable laten dependen apakah mempunyai pengaruh yang substantive. Pengaruh besarnya $f^{2}$ dihutung dengan rumus sebagai berikut:

$f^{2}=\frac{R_{\text {included }}^{2}-R_{\text {excluded }}^{2}}{1-R_{\text {included }}^{2}}$

b. Pengujian Hipotesis

Pengujian hipotesis dapat dilihat dari nilai t-statistik yang menggunakan nilai statistik untuk alpha 5\% maka nilai t-statistik yang digunakan adalah 1,96. Sehingga kriteria penolakan / penerimaan hipotesis adalah Ho ditolak dan Ha diterima ketika t-statistik > 1,96. Sedangkan dilihat dari nilai probabilitas, untuk menolak / menerima hipotesis menggunakan nilai probabilitas mana Ha diterima jika nilai $\mathrm{p}<$ 0,05. Setelah diketahui hasil nilai yang didapatkan kesimpulan apakah Ho ditolak atau Ha diterima, analisis tersebut menggunakan prosedur bootstrapping.

c. Menarik Kesimpulan

Setelah dilakukan semua tahapan-tahapan pengujian kepada semua indikator, langkah terakhir adalah menarik kesimpulan. Kesimpulan dibuat dengan melihat hasil pengujian hipotesis yang telah diiuji untuk melihat faktor-faktor yang berpengaruh pada model penerimaan penggunaan aplikasi dengan integrasi TAM dan TPB.

\section{Pengujian Pilot Study}

1. Perancangan Model Struktural (Inner Model)

Perancangan inner model hubungan antar konstruk didasarkan pada rumusan masalah dan hipotesis penelitian. Perancangan inner model dengan menggunakan software smartPLS 3.2 dapat dilihat pada gambar 3.1

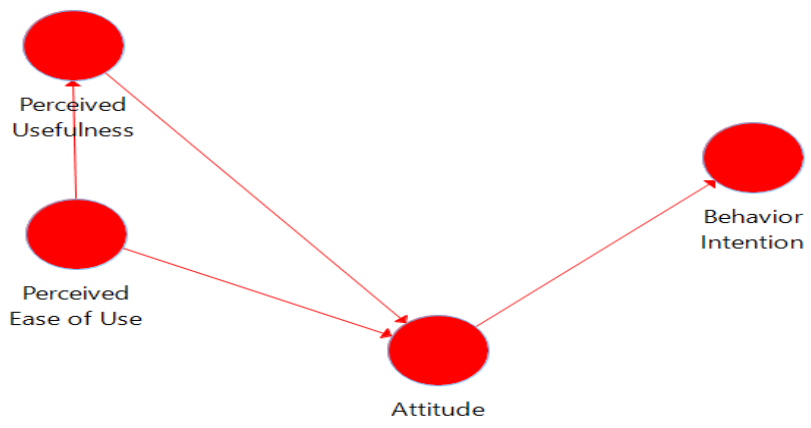

Gambar 3.1

Perancangan Inner Model

\section{Perancangan Model Pengukuran Outer Model}

Indicator dari masing-masing konstruk pada outer model bersifat refleksif. Sehingga arah panah pada model pengukuran dari arah konstruk menuju indikator. Perancangan 
outer model dengan menggunakan software smartPLS v3.2 dapat dilihat dari gambar 3.2

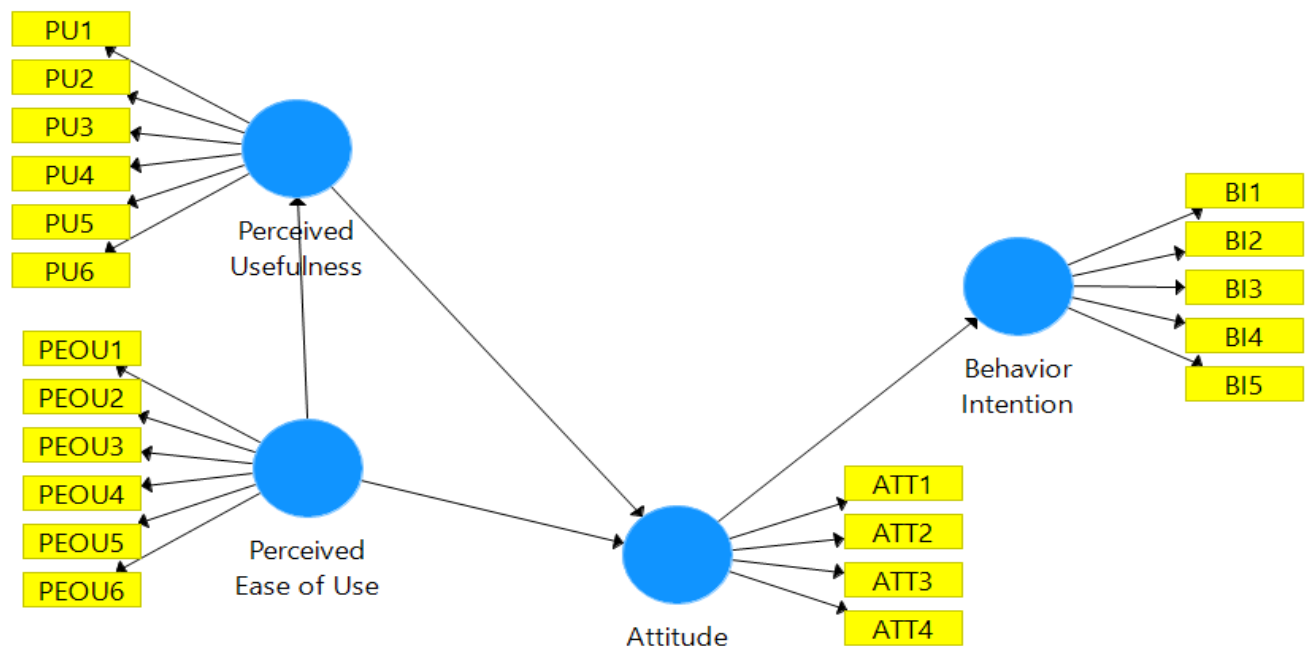

Gambar 3.2 Perancangan Outer Model

3. Menghitung nilai evaluasi Outer Model

a. Validitas Konvergen (Convergent Validity)

Pengujian validitas penelitian ini dihitung dengan menggunakan SmartPLS. Pengujian ini didasarkan nilai outer loading lebih besar dari 0,70. Namun demikian pada riset tahap pengembangan skala, loading 0,50 sampai 0,60 masih dapat diterima (Ghozali, 2014). Berikut hasil dari outer loading untuk setiap indikator-indikator dari olah data menggunakan SmartPLS dapat dilihat pada gambar 3.3

Gambar 3.3

Outer Loading 


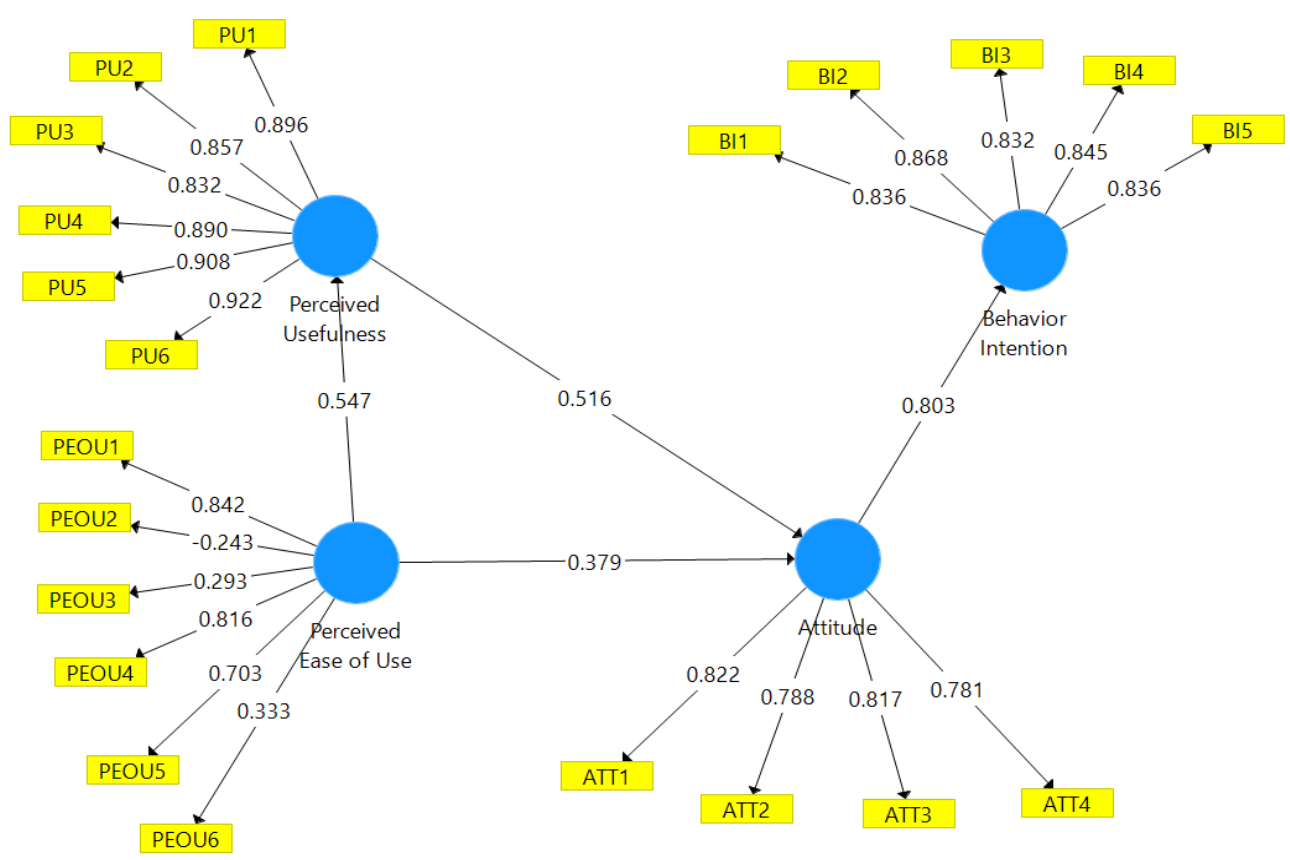

Berdasarkan hasil pengolahan outer loading dengan menggunakan SmartPLS di atas, maka indikator PEOU2, PEOU3, PEOU6 dikeluarkan dari model karena memiliki loading kurang dari 0,5 dan tidak signifikan. Selanjutnya model di re-estimasi kembali dengan membuang indikator PEOU2, PEOU3, dan PEOU6. Hasil output grafik SmartPLS setelah membuang indikator PEOU2 tampak seperti gambar 3.4 berikut ini

Gambar 3.4 . Outer Loading Adjusted

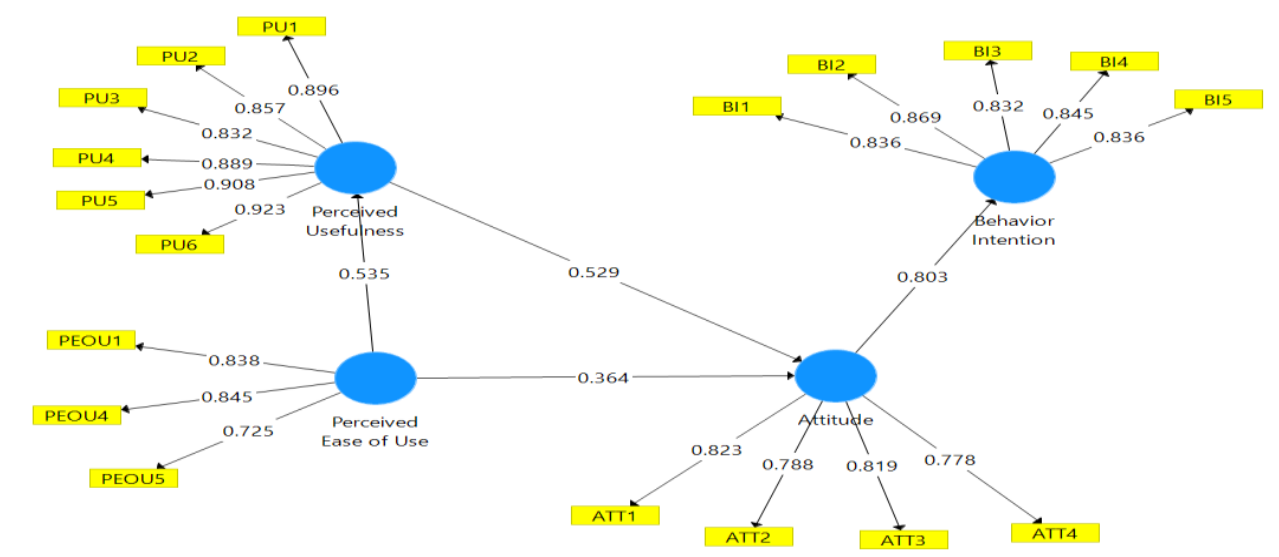

2.Validitas Diskriminan (Discriminant Validity)

Discriminant Validity merupakan indikator relatif yang dapat dilihat pada cross loading antara indikator dengan konstruknya dengan cara pada PLS Alghorithm. Berikut output SmartPLS.

Tabel 3.4 Cross Loading

\begin{tabular}{|l|l|l|l|l|}
\hline & Attitude & $\begin{array}{l}\text { Behavior } \\
\text { Intention }\end{array}$ & $\begin{array}{l}\text { Perceived } \\
\text { Ease of Use }\end{array}$ & $\begin{array}{l}\text { Perceived } \\
\text { Usefulness }\end{array}$ \\
\hline \hline
\end{tabular}

http://jurnal.umb.ac.id/index.php/JAKTA/index

Vol 2. No. 2. Desember 2021 p.341-369 


\begin{tabular}{|l|r|r|r|r|}
\hline ATT1 & $\mathbf{0 , 8 2 3}$ & 0,557 & 0,583 & 0,572 \\
\hline ATT2 & $\mathbf{0 , 7 8 8}$ & 0,623 & 0,368 & 0,711 \\
\hline ATT3 & $\mathbf{0 , 8 1 9}$ & 0,675 & 0,590 & 0,575 \\
\hline ATT4 & $\mathbf{0 , 7 7 8}$ & 0,715 & 0,533 & 0,463 \\
\hline BI1 & 0,737 & $\mathbf{0 , 8 3 6}$ & 0,686 & 0,747 \\
\hline BI2 & 0,776 & $\mathbf{0 , 8 6 9}$ & 0,707 & 0,615 \\
\hline BI3 & 0,618 & $\mathbf{0 , 8 3 2}$ & 0,581 & 0,575 \\
\hline BI4 & 0,654 & $\mathbf{0 , 8 4 5}$ & 0,551 & 0,616 \\
\hline BI5 & 0,559 & $\mathbf{0 , 8 3 6}$ & 0,460 & 0,577 \\
\hline PEOU1 & 0,559 & 0,556 & $\mathbf{0 , 8 3 8}$ & 0,411 \\
\hline PEOU4 & 0,594 & 0,739 & $\mathbf{0 , 8 4 5}$ & 0,573 \\
\hline PEOU5 & 0,334 & 0,321 & $\mathbf{0 , 7 2 5}$ & 0,192 \\
\hline PU1 & 0,670 & 0,633 & 0,411 & $\mathbf{0 , 8 9 6}$ \\
\hline PU2 & 0,550 & 0,574 & 0,415 & $\mathbf{0 , 8 5 7}$ \\
\hline PU3 & 0,594 & 0,701 & 0,460 & $\mathbf{0 , 8 3 2}$ \\
\hline PU4 & 0,709 & 0,752 & 0,522 & $\mathbf{0 , 8 8 9}$ \\
\hline PU5 & 0,649 & 0,698 & 0,557 & $\mathbf{0 , 9 0 8}$ \\
\hline PU6 & 0,651 & 0,589 & 0,456 & $\mathbf{0 , 9 2 3}$ \\
\hline
\end{tabular}

Sumber: Data Diolah 2019.

\section{Average Variance Extracted (AVE)}

Metode lain untuk menilai discriminant validity selain dengan melihat nilai cross loading yaitu dengan melihat akar kuadrat dari AVE untuk setiap konstruk apakah lebih besar daripada korelasi antara konstruk dengan konstruk lainnya.

Tabel 3.5 AVE dan Akar AVE

\begin{tabular}{|l|l|l|}
\hline & $\begin{array}{l}\text { Average Variance } \\
\text { Extracted }(\boldsymbol{A V E})\end{array}$ & Akar AVE \\
\hline Attitude & 0,643 & 0,802 \\
\hline Behavior Intention & 0,712 & 0,844 \\
\hline Perceived Ease of Use & 0,647 & 0,804 \\
\hline Perceived Usefulness & 0,783 & 0,885 \\
\hline
\end{tabular}

Sumber: Data Diolah 2019.

4. Validitas Komposite (Composite Validity)

Uji reabilitas konstruk yang diukur dengan dua criteria yaitu composite validity maupun cronbach alpha di atas 0,70. Berikut output SmartPLS.

Tabel 3.6 Composite Validity dan Cronbach Alpha

\begin{tabular}{|l|c|r|}
\hline & $\begin{array}{l}\text { Composite } \\
\text { Reliability }\end{array}$ & $\begin{array}{l}\text { Cronbach's } \\
\text { Alpha }\end{array}$ \\
\hline Attitude & 0,878 & 0,815 \\
\hline Behavior Intention & 0,925 & 0,899 \\
\hline
\end{tabular}




\begin{tabular}{|l|l|l|}
\hline Perceived Ease of Use & 0,845 & 0,742 \\
\hline Perceived Usefulness & 0,956 & 0,944 \\
\hline
\end{tabular}

Hasil output composite reliability maupun cronbach alpha untuk semua konstruk di atas 0,7. Jadi dapat disimpulkan bahwa konstruk memiliki reabilitas yang baik. Pengujian terhadap model struktural dilakukan dengan melihat nilai R-square yang merupakan uji goodness-fit model. Berikut output SmartPLS:

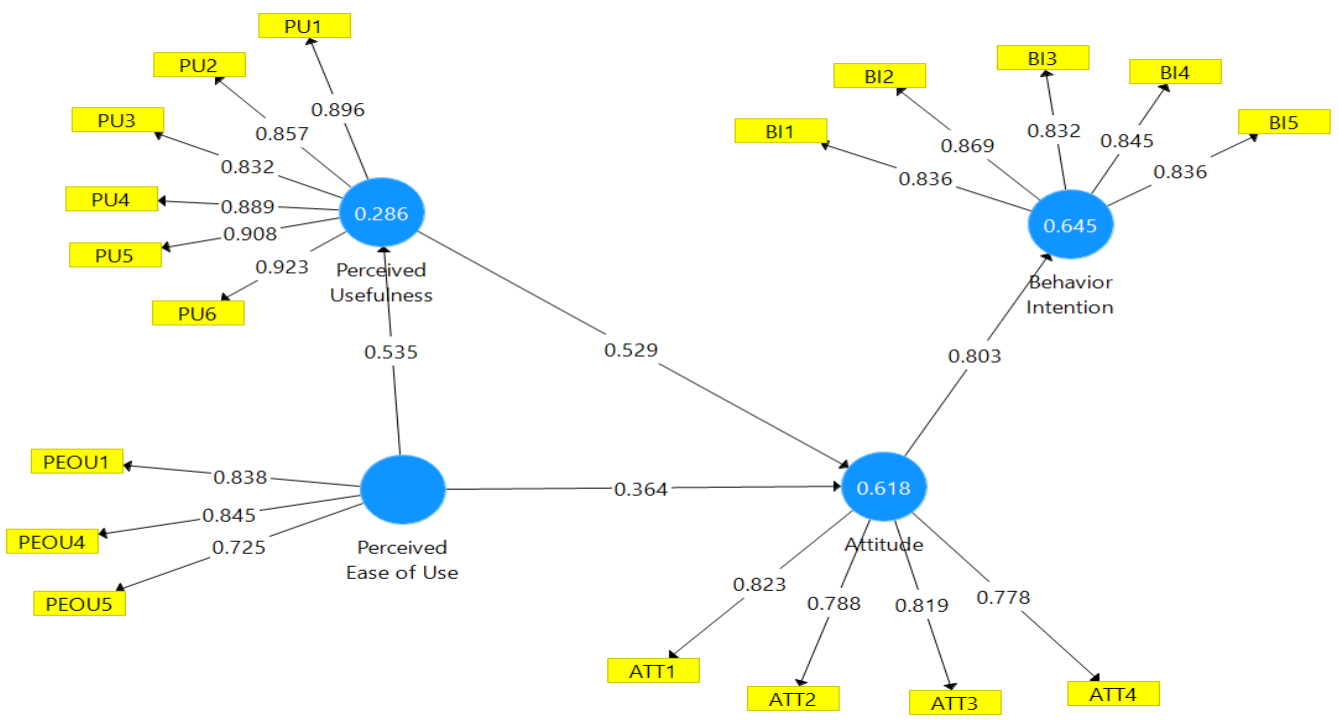

Tabel 3.7 R-Square

\begin{tabular}{|l|r|}
\hline & R Square \\
\hline Attitude & 0,618 \\
\hline Behavior Intention & 0,645 \\
\hline Perceived Usefulness & 0,286 \\
\hline
\end{tabular}

Lalu uji inner model yang kedua adalah melihat signifikansi pengaruh antar variabel penelitian dengan melihat koefisien parameter dan nilai signifikansi $t$ statistik. Dapat dilihat pada tabel 3.8

Tabel 3.8 Path Coefficients

\begin{tabular}{|l|r|r|r|r|r|}
\hline & $\begin{array}{l}\text { Original } \\
\text { Sample (O) }\end{array}$ & $\begin{array}{l}\text { Sample } \\
\text { Mean (M) }\end{array}$ & $\begin{array}{l}\text { Standard } \\
\text { Deviation } \\
\text { (STDEV) }\end{array}$ & $\begin{array}{l}\text { T Statistics } \\
(|\mathrm{O} / \mathrm{STDEV}|)\end{array}$ & $\begin{array}{l}\text { V } \\
\text { Values }\end{array}$ \\
\hline $\begin{array}{l}\text { Attitude -> Behavior } \\
\text { Intention }\end{array}$ & 0,803 & 0,806 & 0,024 & 33,219 & 0,000 \\
\hline $\begin{array}{l}\text { Perceived Ease of Use - } \\
\text { > Attitude }\end{array}$ & 0,364 & 0,368 & 0,069 & 5,289 & 0,000 \\
\hline $\begin{array}{l}\text { Perceived Ease of Use - } \\
\text { > Perceived Usefulness }\end{array}$ & 0,535 & 0,543 & 0,040 & 13,400 & 0,000 \\
\hline $\begin{array}{l}\text { Perceived Usefulness -> } \\
\text { Attitude }\end{array}$ & 0,529 & 0,525 & 0,058 & 9,057 & 0,000 \\
\hline
\end{tabular}

result and disscussion 
Software akuntansi merupakan program yang dibuat untuk memudahkan aktivitas dan pencatatan akuntansi. Semua rangkaian kegiatan dalam akuntansi seperti menjual, posting ke buku besar, menyusun neraca saldo dan laporan keuangan dapat dikerjakan melalui program aplikasi akuntansi. Aplikasi yang cocok bagi para pelaku UKM yaitu aplikasi akuntansi berbasis Android, karena setiap orang sekarang sudah menggunakan smartphone. Salah satu aplikasi akuntansi yang popular di platform android yaitu Akuntansi UKM - Keuangan. Aplikasi Akuntansi UKM - Keuangan merupakan suatu sistem aplikasi keuangan sederhana yang dapat digunakan oleh usaha kecil dan menengah, serta untuk pengelolaan keuangan sehari-hari. Akuntansi UKM Keuangan digunakan untuk memenuhi kebutuhan standar pengelolaan sistem informasi keuangan dalam perusahaan sehingga pencatatan keuangan perusahaan tersistem dengan baik dan benar untuk meminimalisir resiko kebangkrutan. (Google Play Store, 2019).

Aplikasi Akuntansi UKM - Keuangan sangat mudah digunakan untuk yang belum mengerti akuntansi karena di desain simple dan tidak merepotkan dengan kode-kode akuntansi. Aplikasi ini dapat digunakan untuk segala jenis usaha, pengelolaan keuangan pribadi dan pengelolaan perusahaan keluarga dengan laporan otomatis dan lengkap. Aplikasi ini digunakan tanpa syarat, tanpa batasan jumlah transaksi yang bisa diinput, tanpa batasan jumlah entitas yang dimiliki, tanpa batasan periode dalam melihat laporan keuangan dan bisa digunakan secara offline. (Google Play Store, 2019).

\section{A. Menilai Outer Model atau Measurement Model}

Terdapat tiga criteria di dalam penggunaan teknik analisa data dengan SmartPLS untuk menilai outer model yaitu Convergent Validity, Discriminant Validity, dan Composite Reliability. Convergent Validity dari model pengukuran dengan refleksif indikator dinilai berdasarkan korelasi antara item score/component score yang diestimasi dengan software SmartPLS.

1. Analisis signifikansi indikator (Convergent Validity)

Ukuran releksif individual dikatakan tinggi jika berkorelasi lebih dari 0,70 dengan konstruk yang diukur. Namun menurut Chin (dalam Ghozali, 2014) nilai loading 0,5 - 0,6 masih bisa diterima untuk penelitian tahap awal pengembangan skala pengukuran. Dalam penelitian ini akan digunakan nilai loading lebih besar dari 0,60.

\begin{tabular}{cccc}
\multirow{2}{*}{ Variabel } & Tabel 3.9 Outer Loading & \\
& Indikator & Uji 1 & Uji 2 \\
& ATT1 & 0,822 & 0,823 \\
Attitude & ATT2 & 0,788 & 0,788 \\
& ATT3 & 0,817 & 0,819 \\
& ATT4 & 0,781 & 0,778 \\
Behavioral Intention & BI1 & 0,836 & 0,836
\end{tabular}




$\begin{array}{cccc} & \text { BI2 } & 0,868 & 0,869 \\ & \text { BI3 } & 0,832 & 0,832 \\ \text { BI4 } & 0,845 & 0,845 \\ & \text { BI5 } & 0,836 & 0,836 \\ & \text { PEOU1 } & 0,842 & 0,838 \\ & \text { PEOU2 } & \mathbf{- 0 , 2 4 3} & - \\ \text { Perceived Ease of Use } & \text { PEOU3 } & \mathbf{0 , 2 9 3} & - \\ & \text { PEOU4 } & 0,816 & 0,845 \\ & \text { PEOU5 } & 0,703 & 0,725 \\ & \text { PEOU6 } & \mathbf{0 , 3 3 3} & - \\ & \text { PU1 } & 0,896 & 0,896 \\ & \text { PU2 } & 0,857 & 0,857 \\ \text { Perceived Usefulness } & \text { PU3 } & 0,832 & 0,832 \\ & \text { PU4 } & 0,890 & 0,889 \\ & \text { PU5 } & 0,908 & 0,908 \\ & \text { PU6 } & 0,922 & 0,923\end{array}$

Peneliti melakukan pengujian mulai uji 1 dan uji 2. Dapat dilihat pada tabel 4.5, uji 2 semua indikator mempunyai muatan (loading) yang lebih besar dari 0,60. Namun, dari tabel uji 1 terdapat nilai muatan (loading) yang kurang dari 0,60 yaitu terdapat pada Perceived Ease of Use item PEOU2, PEOU3, dan PEOU6 sebesar -0,243, 0,293 dan 0,333 . Nilai item-item yang kurang dari 0,60 harus dihapus dari model sebelum dilakukan uji tahap berikutnya. Setelah dihapus item - item yang mempunyai nilai dibawah 0,60, kemudian dilakukan estimasi ulang untuk memberikan keyakinan semua item telah mempunyai nilai lebih dari 0,60. Berikut adalah hasil estimasi ulang penelitian dapat dilihat pada tabel 4.6

Tabel 4.6 Nilai muatan (outer loading) setelah estimasi ulang

Variabel

Attitude

Perceived Ease of Use
Indikator

ATT1

ATT2

ATT3

ATT4

BI1

$\mathrm{BI} 2$

$\mathrm{BI} 3$

$\mathrm{BI} 4$

BI5

PEOU1

PEOU4
Outer Loading

0,823

0,788

0,819

0,778

0,836

0,869

0,832

0,845

0,836

0,838

0,845
Validitas $(>0,60)$

Valid

Valid

Valid

Valid

Valid

Valid

Valid

Valid

Valid

Valid

Valid 


$\begin{array}{cccc} & \text { PEOU5 } & 0,725 & \text { Valid } \\ & \text { PU1 } & 0,896 & \text { Valid } \\ & \text { PU2 } & 0,857 & \text { Valid } \\ \text { Perceived Usefulness } & \text { PU3 } & 0,832 & \text { Valid } \\ & \text { PU4 } & 0,889 & \text { Valid } \\ & \text { PU5 } & 0,908 & \text { Valid } \\ & \text { PU6 } & 0,923 & \text { Valid }\end{array}$

2. Analisis korelasi indikator (Discriminant Validity)

Discriminant Validity dilakukan untuk memastikan bahwa setiap konsep dari masing variabel laten berbeda dengan variabel lainnya. Model mempunyai discriminant validity yang baik jika setiap nilai loading dari setiap indikator dari sebuah variabel laten memiliki nilai loading yang paling besar dibandingkan dengan nilai loading lain terhadap variabel laten lainnya. Hasil pengujian discriminant validity yang diperoleh dapat dilihat di tabel 4.7

Tabel 4.7 Nilai Discriminant Validity (Cross Loading)

$\begin{array}{lccc}\text { Indikator Attitude } & \begin{array}{c}\text { Behavior } \\ \text { Intention }\end{array} & \begin{array}{c}\text { Perceived } \\ \text { Ease of } \\ \text { Use }\end{array} & \begin{array}{c}\text { Perceived } \\ \text { Usefulness }\end{array} \\ & & \end{array}$

\begin{tabular}{c|l|lll|}
\cline { 2 - 2 } ATT1 & $\mathbf{0 , 8 2 3}$ & 0,557 & 0,583 & 0,572 \\
\cline { 2 - 2 } ATT2 & $\mathbf{0 , 7 8 8}$ & 0,623 & 0,368 & 0,711 \\
\cline { 2 - 2 } ATT3 & $\mathbf{0 , 8 1 9}$ & 0,675 & 0,590 & 0,575 \\
\cline { 2 - 2 } BI1 & $\mathbf{0 , 7 7 8}$ & 0,715 & 0,533 & 0,463 \\
BI2 & 0,737 & $\mathbf{0 , 8 3 6}$ & 0,686 & 0,747 \\
BI3 & 0,776 & $\mathbf{0 , 8 6 9}$ & 0,707 & 0,615 \\
BI4 & 0,618 & $\mathbf{0 , 8 3 2}$ & 0,581 & 0,575 \\
BI5 & 0,654 & $\mathbf{0 , 8 4 5}$ & 0,551 & 0,616 \\
PEOU1 & 0,559 & $\mathbf{0 , 8 3 6}$ & 0,460 & 0,577 \\
PEOU4 & 0,559 & 0,556 & $\mathbf{0 , 8 3 8}$ & 0,411 \\
PEOU5 & 0,594 & 0,739 & $\mathbf{0 , 8 4 5}$ & 0,573 \\
PU1 & 0,334 & 0,321 & $\mathbf{0 , 7 2 5}$ & 0,192 \\
PU2 & 0,670 & 0,633 & 0,411 & $\mathbf{0 , 8 9 6}$ \\
PU3 & 0,550 & 0,574 & 0,415 & $\mathbf{0 , 8 5 7}$ \\
PU4 & 0,594 & 0,701 & 0,460 & $\mathbf{0 , 8 3 2}$ \\
PU5 & 0,709 & 0,752 & 0,522 & $\mathbf{0 , 8 8 9}$ \\
PU6 & 0,649 & 0,698 & 0,557 & $\mathbf{0 , 9 0 8}$ \\
\hline
\end{tabular}


Dari tabel 4.7 dapat dilihat bahwa beberapa nilai loading factor untuk setiap indikator dari masing-masing variabel laten memiliki nilai loading factor yang paling besar dibanding nilai loading jika dihubungkan dengan variabel laten lainnya. Hal ini berarti bahwa setiap variabel laten memiliki discriminant validity yang baik dimana variabel laten memiliki pengukur yang berkorelasi tinggi dengan konstruknya.

\section{Average Variance Extracted (AVE)}

Metode lain untuk menilai discriminant validity selain dengan melihat nilai cross loading yaitu dengan melihat akar kuadrat dari AVE untuk setiap konstruk apakah lebih besar daripada korelasi antara konstruk dengan konstruk lainnya.

\section{Tabel 4.8 AVE dan Akar AVE}

$\begin{array}{llll} & \begin{array}{l}\text { Average } \\ \text { Variance }\end{array} & \text { Akar } & \text { Keterangan } \\ & \begin{array}{l}\text { Extracted }(\boldsymbol{A V E}) \\ \text { Attitude }\end{array} & & \\ \text { Behavior Intention } & 0,643 & 0,802 & \text { Valid } \\ \text { Perceived Ease of Use } & 0,712 & 0,844 & \text { Valid } \\ \text { Perceived Usefulness } & 0,647 & 0,804 & \text { Valid } \\ & 0,783 & 0,885 & \text { Valid }\end{array}$

Dilihat dari tabel 4.8 merupakan Average Variance Extracted (AVE), yaitu nilai yang menunjukkan bahwa setiap variabel laten dengan indikator memiliki hubungan yang sesuai dan lebih besar dari standar AVE 0,50.

4. Uji Reliabilitas/Composite Reliability

Uji reliabilitas konstruk diukur dengan dua kriteria yaitu composite reliability dan cronbach alpha dari indikator - indikator yang mengukur suatu konstruk. Dalam penelitian ini uji reliabilitas mempunyai tujuan untuk menilai sejauh mana alat ukur yang digunakan dapat dipercaya. Konstruk dinyatakan reliabel jika nilai composite reliability dan cronbach alpha diatas 0,70 .

Tabel 4.9 Composite Reliability dan Cronbach Alpha

$\begin{array}{lc}\text { Composite } & \text { Cronbach } \\ \text { Reliability } & \text { Alpha }\end{array}$

\begin{tabular}{cccc|} 
Attitude & 0,878 & 0,815 \\
Behavior Intention & 0,925 & 0,899 \\
Perceived Ease of Use & 0,845 & 0,742 \\
Perceived Usefulness & 0,956 & 0,944 \\
\hline
\end{tabular}

Berdasarkan hasil tabel di atas menunjukkan bahwa nilai dari Composite Reliability dan Cronbach Alpha diatas 0,70. Dapat disimpulkan bahwa kuesioner yang digunakan sudah konsisten dan memiliki reliabilitas yang baik seebagaimana kriteria yang direkomendasikan. 


\section{B. Pengujian Model Struktural (Inner Model)}

Setelah melakukan pengujian measurement (outer model), maka selanjutnya melakukan pengujian inner model atau model struktural dengan melihat nilai R-square pada konstruk endogen yang merupakan uji goodness-fit model. Model struktural yang mempunyai hasil $\mathrm{R}$-square $\left(\mathrm{R}^{2}\right)$ sebesar 0,33 dikatakan bahwa model "moderat", dan $\mathrm{R}$ square $\left(\mathrm{R}^{2}\right)$ sebesar 0,19 dikatakan bahwa model "lemah" (Ghozali, 2014). Dalam menilai model dengan PLS dimulai dengan melihat R-square untuk setiap konstruk endogen. Berikut output dengan menggunakan SmartPLS:

\section{Tabel 4.10 Nilai R-square}

\section{R Square}

$\begin{array}{ll}\text { Attitude } & 0,618 \\ \text { Behavior Intention } & 0,645 \\ \text { Perceived Usefulness } & 0,286\end{array}$

Sumber: Data Diolah 2019.

Dilihat dari hasil output R-square di atas mengidentifikasikan bahwa terdapat dua konstruk yang termasuk dalam kategori moderat dan satu konstruk kategori lemah. Interpretasi dari output R-square dapat dijelaskan sebagai berikut:

1. Nilai R-square $\left(\mathrm{R}^{2}\right)$ konstruk endogen Attitude pada model penelitian ini sebesar 0,618. Hal ini berarti konstruk Perceived Usefulness dan Perceived Ease of Use hanya dapat menjelaskan konstruk Attitude sebesar 61,8\% dan sisanya dijelaskan oleh variabel lain di luar model.

2. Nilai R-square $\left(\mathrm{R}^{2}\right)$ konstruk endogen Behavior Intention pada model penelitian ini sebesar 0,645. Hal ini berarti konstruk Attitude hanya dapat menjelaskan konstruk Behavior Intention sebesar $64,5 \%$ dan sisanya dijelaskan oleh variabel lain di luar model.

3. Nilai R-square $\left(\mathrm{R}^{2}\right)$ konstruk endogen Perceived Usefulness pada model ini sebesar 0,286. Hal ini berarti konstruk Perceived Ease of Use hanya dapat menjelaskan konstruk Perceived Usefulness sebesar 28,6\% dan sisanya dijelaskan oleh variabel lain di luar model.

Pada penelitian ini, selain menguji nilai R-square juga dilakukan tahap pengujian dengan goodness of fit, yang diketahui melalui nilai $\left(\mathrm{Q}^{2}\right)$. Nilai $\left(\mathrm{Q}^{2}\right)$ mempunyai arti sama dengan koefisien determinan (R-square) pada analisis regresi. Dimana semakin tinggi nilai R-square, maka model dapat dikatakan semakin fit dengan data. Tabel 4.10 $\mathrm{R}$-square dapat dihitung nilai $\left(\mathrm{Q}^{2}\right)$ sebagai berikut:

Nilai $Q^{2}=1-[(1-0,618) \times(1-0,645) \times(1-0,286)]$

$=1-(0,382 \times 0,355 \times 0,714)$

$=0,903$ 
Hasil perhitungan dapat diketahui nilai $\mathrm{Q}^{2}$ sebesar 0,903. Hal ini berarti besarnya keberagaman dari data penelitian yang dapat dijelaskan model struktural yang dikembangkan dalam penelitian ini yaitu sebesar 90\%. Maka dapat dikatakan model struktural penelitian ini telah memiliki goodness of fit yang baik.

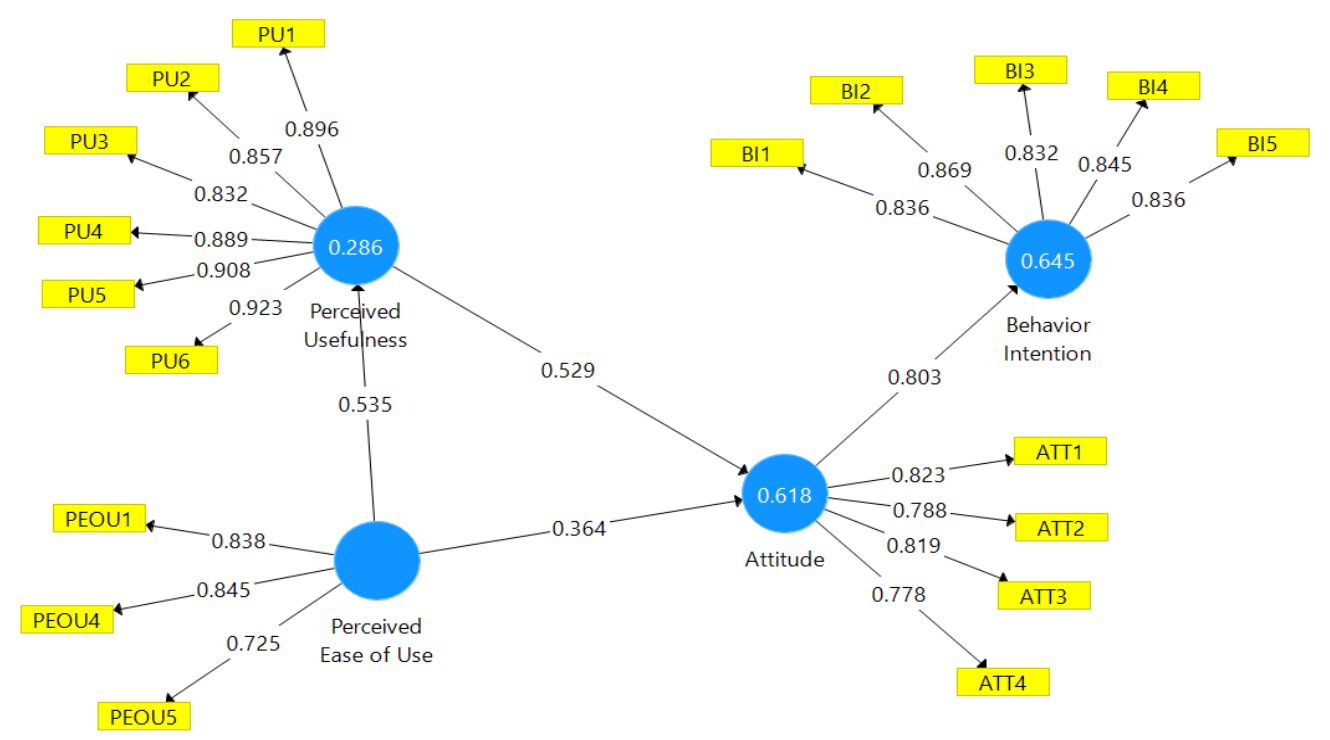

Gambar 4.1 Path Diagram Model Struktural

\section{Pengujian Hipotesis Pengaruh Parsial}

Signifikansi parameter yang di estimasi memberikan informasi yang sangat berguna mengenai hubungan antara variabel - variabel penelitian. Dasar yang digunakan dalam menguji hipotesis adalah nilai yang terdapat pada output result for inner weight pada tabel 4.11

Tabel 4.11 Path Coefficient (Mean, STDEV, T-Values, P-Values)

Original Sample Standard T Statistics $\mathbf{P}$

Sample Mean Deviation (|O/STDEV $\mid)$ Values

(O) (M) (STDEV)

\begin{tabular}{|c|c|c|c|c|c|}
\hline Attitude -> & 0,803 & 0,806 & 0,024 & 33,219 & 0,000 \\
\hline Behavior Intention & & & & & \\
\hline $\begin{array}{l}\text { Perceived Ease of } \\
\text { Use -> Attitude }\end{array}$ & 0,364 & 0,368 & 0,069 & 5,289 & 0,000 \\
\hline $\begin{array}{l}\text { Perceived Ease of } \\
\text { Use -> Perceived } \\
\text { Usefulness }\end{array}$ & 0,535 & 0,543 & 0,040 & 13,400 & 0,000 \\
\hline Perceived & 0,529 & 0,525 & 0,058 & 9,057 & 0,000 \\
\hline
\end{tabular}

Usefulness ->

Attitude

Hasil pengujian hipotesis secara keseluruhan dapat dirangkum sebagai berikut: 
Tabel 4.12 Pengujian Hipotesis

Hipotesis

H1: Perceived Usefulness berpengaruh terhadap Attitude

$\mathrm{H} 2$ : Perceived Ease of Use berpengaruh terhadap Attitude

H3: Perceived Ease of Use berpengaruh terhadap Usefulness

$\mathrm{H} 4$ : Attitude berpengaruh terhadap

Behavior Intention
Nilai P-Value Kesimpulan

$0,000<0,05 \quad$ Diterima

$0,000<0,05 \quad$ Diterima

$0,000<0,05 \quad$ Diterima

$0,000<0,05 \quad$ Diterima

Hasil pengujian hipotesis menunjukkan bahwa pengaruh perceived usefulness terhadap attitude menunjukkan nilai $\mathrm{P}-\mathrm{V}$ alue $<0,05$. Hasil ini berarti bahwa perceived usefulness terhadap attitude memiliki pengaruh yang signifikan, yang berarti sesuai dengan hipotesis dimana perceived usefulness berpengaruh terhadap attitude. Hasil pengujian hipotesis menunjukkan bahwa pengaruh perceived ease of use terhadap perceived usefulness menunjukkan nilai P-Value $<0,05$. Hasil ini berarti bahwa perceived ease of use terhadap perceived usefulness memiliki pengaruh yang signifikan, yang berarti sesuai dengan hipotesis dimana perceived ease of use terhadap perceived usefulness. Hasil pengujian hipotesis menunjukkan bahwa pengaruh perceived ease of use terhadap attitude menunjukkan nilai $\mathrm{P}-\mathrm{Value}<0,05$. Hasil ini berarti bahwa perceived ease of use terhadap attitude memiliki pengaruh yang signifikan, yang berarti sesuai dengan hipotesis dimana perceived ease of use berpengaruh terhadap attitude. Hasil pengujian hipotesis menunjukkan bahwa pengaruh attitude terhadap behavior intention menunjukkan nilai P-Value $<0,05$. Hasil ini berarti bahwa attitude terhadap behavior intention memiliki pengaruh yang signifikan, yang berarti sesuai dengan hipotesis dimana attitude berpengaruh terhadap behavior intention.

\section{Pembahasan}

a. $\quad$ Perceived Usefulness berpengaruh terhadap Attitude.

Penerimaan $\mathrm{H} 1$ ini mengindikasikan bahwa semakin tinggi perceived usefulness pelaku UKM terhadap aplikasi akuntansi, maka attitude pelaku UKM semakin tinggi untuk menggunakan aplikasi akuntansi. Begitu sebaliknya apabila perceived usefulness pelaku UKM untuk menerima aplikasi akuntansi semakin rendah, maka attitude pelaku UKM semakin rendah untuk menggunakan aplikasi akuntansi. Hasil penelitian ini sejalan dengan hasil penelitian Lu et al, (2010), Hung et al, (2006), Zhang et al, (2011) dan Al-Shafi \& Weerakody (2009) yang menyatakan bahwa perceived usefulness berpengaruh signifikan terhadap attitude.

Dari penelitian ini, dapat dinyatakan bahwa pelaku UKM memersepsikan diri mereka bahwa dengan menggunakan sistem aplikasi akuntansi dapat memberikan pengguna manfaat, maka pengguna memiliki kecenderungan untuk menggunakan aplikasi. Ketika 
pengguna merasa yakin dengan menggunakan aplikasi akuntansi berguna dalam meningkatkan bisnis mereka, maka pelaku UKM memilih untuk menggunakan aplikasi akuntansi karena dapat membantu pelaku UKM mempercepat kegiatan transaksi, meningkatkan produktivitas mereka dan membantu melakukan pembukuan keuangan lebih cepat.

b. Perceived Ease of Use berpengaruh terhadap Attitude

Penerimaan $\mathrm{H} 2$ ini mengindikasikan bahwa semakin tinggi perceived ease of use pelaku UKM terhadap aplikasi akuntansi, maka attitude pelaku UKM semakin tinggi untuk menggunakan aplikasi akuntansi. Begitu sebaliknya apabila perceived ease of use aplikasi akuntansi rendah, maka attitude pelaku UKM semakin rendah untuk menggunakan aplikasi akuntansi. Penerimaan ini didukung oleh hasil data penelitian pengisian kuesioner yang didapat peneliti. Hasil penelitian ini sejalan dengan hasil penelitian Lu et al. (2010), Hung et al. (2006), Zhang et al (2011), Lin et al. (2011) yang menyatakan bahwa perceived usefulness berpengaruh signifikan terhadap attitude.

Dari hasil penelitian ini, dapat dinyatakan bahwa pelaku UKM dapat memersepsikan diri mereka mudah untuk untuk mempelajari cara menggunakan aplikasi akuntansi, maka pelaku UKM lebih cenderung memiliki sikap positif untuk menggunakan aplikasi akuntansi. Pelaku UKM meyakini bahwa mengoperasikan aplikasi akuntansi sangat jelas dan mudah dipahami, maka pelaku UKM memiliki kecenderungan menggunakan aplikasi akuntansi.

\section{Perceived Ease of Use berpengaruh terhadap Perceived Usefulness}

Untuk mengetahui pengaruh faktor perceived ease of use terhadap perceived usefulness dari pelaku UKM pada aplikasi akuntansi dapat dilihat pada hasil analisis yang telah dilakukan dengan menggunakan tool SmartPLS. Berdasarkan analisis didapatkan bahwa faktor perceived ease of use berpengaruh signifikan positif terhadap perceived usefulness. Variabel perceived ease of use yang dimaksud yakni pelaku UKM menganggap mudah dan tidak memerlukan usaha yang besar dalam menggunakan aplikasi akuntansi, sedangkan variabel perceived usefulness yang dimaksud yakni pelaku UKM percaya aplikasi akuntansi memberikan manfaat yang dapat dirasakan oleh penggunanya. Dapat dilihat dari hasil nilai $P$ Values dari hubungan kedua variabel tersebut mencapai angka 0,000 (kurang dari 0,05) dan nilai T-statistik sebesar 13,400 (lebih dari 1,96) yang dapat diartikan bahwa terdapat pengaruh positif signifikan antara dua variabel tersebut.

Penerimaan $\mathrm{H} 3$ ini mengindikasikan bahwa semakin tinggi perceived ease of use aplikasi akuntansi, maka perceived usefulness akan semakin tinggi juga. Begitu sebaliknya apabila perceived ease of use pelaku UKM terhadap aplikasi akuntansi semakin rendah, maka perceived usefulness pelaku UKM semakin rendah untuk menggunakan aplikasi akuntansi. Penerimaan ini didukung oleh hasil data penelitian pengisian kuesioner yang didapat peneliti. Hasil penelitian ini sejalan dengan hasil penelitian Lu et al. (2010), Al-Shafi dan Weerakkody (2009), Zhang et al. (2011), Lin et al. (2011) yang menyatakan bahwa perceived ease of use berpengaruh terhadap perceived usefulness. 
Dari hasil penelitian ini, dapat dinyatakan bahwa pelaku UKM dapat memersepsikan diri mereka mudah untuk menggunakan aplikasi akuntansi, maka pengguna merasa mendapat manfaat dari menggunakan aplikasi akuntansi. Pelaku UKM merasa yakin mengoperasikan aplikasi akuntansi sangat jelas dan mudah dipahami, maka pelaku UKM dapat merasakan manfaat yang diberikan aplikasi akuntansi seperti meningkatkan keefektifan pengguna (Yusmaniarti \& Ekowati, 2019). Hal ini berarti semakin aplikasi akuntansi mudah dipahami oleh pengguna, maka pengguna akan semakin percaya akan merasakan manfaat ketika menggunakan aplikasi akantansi.

c. Attitude berpengaruh terhadap Behavior Intention

Untuk mengetahui pengaruh faktor attitude terhadap behavior intention dari pelaku UKM pada aplikasi akuntansi dapat dilihat pada hasil analisis yang telah dilakukan dengan menggunakan tool SmartPLS. Berdasarkan analisis didapatkan bahwa faktor attitude berpengaruh signifikan positif terhadap behavior intention. Variabel attitude yang dimaksud yakni perasaan positif atau negatif pelaku UKM terhadap aplikasi akuntansi (apakah pelaku UKM menerima atau menolak untuk menggunakan aplikasi akuntansi), sedangkan variabel behavior intention yang dimaksud yakni keinginan atau niat pelaku UKM untuk menggunakan aplikasi akuntansi. Dapat dilihat dari hasil nilai $P$ Values dari hubungan kedua variabel tersebut mencapai angka 0,000 (kurang dari 0,05) dan nilai T-statistik sebesar 33,219 (lebih dari 1,96) yang dapat diartikan bahwa terdapat pengaruh positif signifikan antara dua variabel tersebut.

Penerimaan H4 mengindikasikan bahwa jika semakin tinggi attitude pelaku UKM, maka semakin tinggi behavior intention pelaku UKM untuk menggunakan aplikasi akuntansi. Begitu sebaliknya, jika semakin rendah attitude pelaku UKM, maka semakin rendah behavior intention pelaku UKM untuk menggunakan aplikasi akuntansi. Penerimaan ini didukung oleh hasil data penelitian pengisian kuesioner yang didapat peneliti. Hasil penelitian ini sejalan dengan hasil penelitian Lu et al. (2010), Zhang et al. (2011), Lin et al. (2011), Sahu dan Gupta (2007) yang menyatakan bahwa attitude berpengaruh terhadap behavior intention. Dari hasil penelitian ini, dapat dinyatakan bahwa pelaku UKM memiliki kecenderungan yang tinggi untuk menggunakan aplikasi akuntansi karena pelaku UKM dapat mengambil manfaat dan merasa mudah untuk mengoperasikan aplikasi akuntansi. Maka hal itu akan berdampak timbulnya sikap positif yang mendorong niat pelaku UKM untuk menggunakan aplikasi akuntansi.

\section{Conclusions}

Perceived usefulness memiliki pengaruh yang signifikan terhadap attitude yang berarti sesuai dengan hipotesis dimana perceived usefulness berpengaruh positif terhadap attitude. Pelaku UKM merasa aplikasi akuntansi akan memberikan manfaat dalam usaha mereka, sehingga pelaku UKM mempunyai sikap positif untuk mengunakan aplikasi akuntansi.

Perceived ease of use berpengaruh terhadap attitude yang berarti sesuai dengan hipotesis dimana perceived ease of use berpengaruh positif terhadap attitude. Pelaku UKM merasa mudah untuk mengoperasikan aplikasi akuntansi, sehingga pelaku UKM lebih cenderung mempunyai sikap yang optimis untuk menggunakan aplikasi akuntansi. 
Perceived ease of use mempengaruhi perceived usefulness yang berarti sesuai dengan hipotesis dimana perceived ease of use berpengaruh positif terhadap perceived usefulness. pelaku UKM memersepsikan mudah menggunakan aplikasi akuntansi, sehingga pelaku UKM dapat merasakan ada manfaat yang akan diberikan oleh aplikasi akuntansi.Attitude berpengaruh signifikan terhadap behavior intention yang berarti sesuai dengan hipotesis dimana attitude berpengaruh positif terhadap behavior intention. Hal ini berarti pelaku UKM mempunyai sikap positif untuk menggunakan aplikasi akuntansi karena mereka memersepsikan aplikasi akuntansi mudah digunakan dan percaya ada manfaat dari aplikasi akuntansi, sehingga ini menimbulkan peningkatan niat penggunaan aplikasi akuntansi. 


\section{DAFTAR PUSTAKA}

Al Fatta, Hanif. 2007. Analisis dan Perancangan Sistem Informasi, Yogyakarta : ANDI. Al-Shafi, S., \& Weerakkody, V. 2007. Implementing and Managing E-Government in The State of Qatar: A Citizens' Perspective. Electronic Government, an International Journal, 4(4), 436 - 450.

Amanda, Kurnia Rizki dan MI Mitha D.R. 2017. Faktor-Faktor yang Mempengaruhi Niat Penggunaan Sistem Informasi Terkomputerisasi pada UKM (Pendekatan Theory of Planned Behavior). Fakultas Ekonomika dan Bisnis Jurusan Akuntansi-Universitas Kristen Satya Wacana. Jurnal Akuntansi Vol. 9 No. 1 Mei 2017: 23 - 33.

Amoroso, D.L and Gardner, C. 2004. Development of an Instrument to Measure the Acceptance of Internet Technology by Consumers. Proceedings of the 37th Hawaii International Conference on System Sciences.

Bodnar, George H. and William S. Hopwood. 2004. Sistem Informasi Akuntansi. Edisi Kesembilan. Diterjemahkan oleh: Julianto Agung Saputra dan Lilis Setiawati. Andi, Yogyakarta.

Darmaningtyas, I Gusti Bagus dan Ketut Alit Suardana. 2017. Pengaruh Technology Acceptance Model (TAM) dalam Penggunaan Software Oleh Auditor yang Berimplikasi Pada Kinerja Auditor. Fakultas Ekonomi dan Bisnis Universitas Udayana. Vol 21.3. Desember.

Davis, F.D. 1985. A Technology Acceptance Model for Empirically Testing New-End User Information Systems: Theory and Results. Disertasi. Massachusetts Institute of Technology.

Davis, F.D. 1989. "Perceived Usefulness, Perceived Ease of Use, and user acceptance of Information Technology. "Management Information System Quarterly, Vol. 13, pp.319-340.

Dreana. 2012. Analisis Faktor-Faktor Yang Mempengaruhi Penerimaan Pengguna SIMAWEB Di Fakultas Ekonomika Dan Bisnis Universitas Diponegoro : Integrasi TAM Dan TPB. Undergraduate Thesis, Fakultas Ekonomika dan Bisnis, Universitas Diponegoro Semarang.

Ghozali, Imam dan Hengky Latan. 2015. Partial Least Squares Konsep, Teknik dan Aplikasi Menggunakan Program SmartPLS 3.0 Untuk Penelitian Empiris. Edisi Dua. Badan Penerbit-Undip.

Ghozali, Imam. 2014. Structural Equation Modeling, Metode Alternatif denan Partial Least Square (PLS). Edisi Keempat. Semarang : Badan Penerbit Universitas Diponegoro.

Hung, S.-Y., Chang, C.-M., \& Yu, T.-J. (2006). Determinants of User Acceptance of The Government Services: The Case of Online Tax Filing and Payment System Government Information Quarterly, 23, 97 - 122. Doi: 10.1016/j.giq.2005.11.005

Igbaria, M., Gumairaes, T. and Davos, G.B. 1995. "Testing The Determinants of Microcomputer Usage Via a Structural Equation Model”. Journal of Management Information System, Vol.11, No.4, pp.87-114.

Jogiyanto. 2005. Analisis dan desain Sistem Informasi. Andi, Yogyakarta. 
2007. Sistem Informasi Keperilakuan. Yogyakarta. Penerbit: Andi.

2008. Sistem Informasi Keprilakuan. Edisi Revisi. Yogyakarta. Penerbit: Andi.

Jun Dai and He-li. 2013. Understanding Usage and Value of Audit Analytics for Internal Auditors: An Institutional Approach. Journal of Information \& Management. 2(1): h: 1-22.

Kuncoro, Mudrajad. 2007. "Catatan Tentang Sektor Industri \& UMKM 10 tahun Pasca Krisis" Makalah Seminar PSAK.

Lin, F., Fofanah, S. S., \& Liang, D. 2011. Assessing Citizen Adoption of E-Government Initiatives in Gambia: A Validation of The Technology Acceptance Model in Information Systems Success. Government Information Quarterly, 28, 271 - 279. doi:10.1016/j.giq.2010.09.004.

Lu et al. 2010. An Empirical Study of Online Tax Filing Acceptance Model: Integrating $T A M$ and TPB. Research Paper, African Journal of Business Management Vol. 4(5), pp. 800-810. http//www.academicjournals.org/AJBM.

McClelland, D.C. (1987). Human Motivation. New York : Cambridge University Press.

Mulyono, Imam. 2009. Uji Empiris Model Kesuksesan Sistem Informasi Keuangan Daerah (Sikd) Dalam Rangka Peningkatan Transparasi Dan Akuntabilitas Keuangan Daerah. Politeknik Negeri Malang.

Nader, J. C. 1992. Prentice Hall's Illustrated Dictionary of computing. New South Wales: Prentice Hall Inc.

Oladipupo, Muhrtala Tijani. 2014. Built-In Functions and Features of Data Analysis Software: Predictors of Optimal Deployment for Continuous Audit Assurance. Scholars Journal of Economics, Business and Management. 1(1):h:7-18

Paidi Paidi, Yusmaniarti,Y., D. W. (2017). Membuat Laporan Keuangan Menggunakan MYOB Versi 19.6 (S. Empat (ed.); Edisi 1). Salemba Empat Jakarta.

Rosita. 2013. "Analisis Faktor-Faktor yang Mempengaruhi Minat Penggunaan Sistem Informasi Akuntansi pada UKM (Studi Empiris pada UKM di Kabupaten Karanganyar)". Graduasi, Vol. 29 Edisi Maret 2013.

Sahu, G. P., \& Gupta, M. P. 2007. User's Acceptance of E-Government: A Study of Indian Central Excise. International Journal of Electric Government Research, 3(3), 1 - 21. Doi:10.4018/jegr.200707010.

Santoso, Budi. 2004. Pengaruh Percieved Usefulness, Perceived Ease of Use, dan Perceived Enjoyment Terhadap Penerimaan Teknologi Informasi (Studi Empiris di Kabupaten Sragen). Jurnal Studi Akuntansi Indonesia. 3(1): h: 1-15.

Sarana. 2000. Pengaruh Persepsi Kemudahan, Persepsi KemanfaatanKecemasan, Sikap dan Penggunaan Mikro Komputerterhadap hasil Kerja Akuntan Pendidik. Tesis. Program Pasca Sarjana Magister Akuntansi Universitas Diponegoro. Semarang

Shinta, Eka Kartika. 2009. Analisis Proses Penerimaan Sistem Informasi iCons Dengan Menggunakan Technology Acceptance Model pada Karyawan PT. Bank Negara Indonesia (Persero) Tbk. Di Kota Semarang. Tesis Universitas Diponegoro.

Singarimbun, Masri dan Sofyan Efendi . 1995. Metode Penelitian Survei. Jakarta: LP3ES. 
Sjazna, B. 1996. "Empirical Evaluation of The Revised Technology Acceptance Model”. Management Science, Vol.42, No.2, pp.85-92.

Sugiyono. 2008. Metode Penelitian Bisnis. Bandung: Alfabeta . 2013. Metode Penelitian Kuantitatif, Kualitatif, dan RnD. Bandung: Alfabeta.

Sun, H., dan Zhang, P. 2003. A New Perspective to Analyze User Technology Acceptance. Working Paper. Syracuse University. New York

Sutanta E. 2003. Sistem Informasi Manajemen Edisi pertama. Yogyakarta: Graha Ilmu.

Sutedjo B. 2002. Perencanaan dan Pembangunan Sistem Informasi. Yogyakarta: Andi Offset.

Undang-Undang Republik Indonesia. Nomor 20. Tahun 2008. Usaha Mikro, Kecil, dan Menengah.

Venkatesh, V., and Davis, F.D. 2000. "A Theoritical Extension of the Technology Acceptance Model: Four Longitudinal Field Studies”. Management Science, Vol.46, No.2, Pebruari, pp.186-204.

Venkatesh, V. and Moris, M.G. 2002. “Why Don't Men Ever Stop to Ask for Directions? Gender, Social Influence and Their Role in Technology Acceptance and Usage Behavior”. MIS Quarterly, Vol.24, No.1, March, pp 115-139.

Wibisono, Arif Kunto. 2011. Analisis dan Pembuatan aplikasi akuntansi berbasis web pada International Islamic University College (IIUC). Universitas Islam Negeri Syarif Hidayatullah, Jakarta.

Widarjono. 2015. Analisis Multivariat Terapan. Edisi Kedua. UPP STIM YKPN, Yogyakarta.

Wiyono, Adrianto Sugiarto. 2008. "Evaluasi Perilaku Penerimaan Wajib Pajak Terhadap Penggunaan E-filing Sebagai Sarana Pelaporan Pajak Secara Online dan Realtime”. Jurnal Riset Akuntansi Indonesia. Vol. 11 (2) Hal. 117-132.

Yamin, Sofyan dan Heri Kurniawan. 2011. Generasi Baru Mengolah Data Penelitian dengan Partial Least Square Path Modeling. Jakarta: Salemba Empat.

Yusmaniarti, Y., \& Ekowati, S. (2019). Laporan Keuangan Koperasi Berbasis Media Excel For Accounting (EFA). Jurnal Pengabdian Masyarakat Bumi Raflesia, 2(1). https://doi.org/10.36085/jpmbr.v2i1.294

Zhang, N., Guo, X, \& Chen, G. 2011. Why Adoption and Use Behavior of IT/IS Cannot Last? - Two Studies in China. Information Sistem Frontiers, 13, 381 - 395. Doi:10.1007/s10796-010-9288-3. 